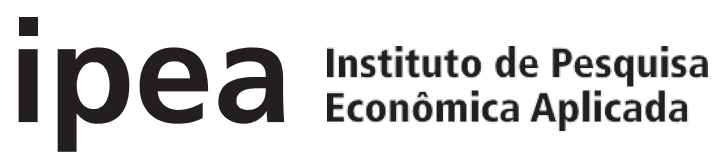

\begin{tabular}{|c|c|}
\hline Título do capítulo & $\begin{array}{l}\text { CAPÍTULO } 4 \\
\text { VENEZUELA: DA DESCENTRALIZAÇÃO IMPERFEITA À } \\
\text { CENTRALIZAÇÃO ABSOLUTA }\end{array}$ \\
\hline Autor(es) & $\begin{array}{l}\text { Ignacio Cardona } \\
\text { Luis Schloeter } \\
\text { Carlos Urdaneta Troconis }\end{array}$ \\
\hline DOI & DOI: http://dx.doi.org/10.38116/978-65-5635-017-2cap4 \\
\hline Título do livro & $\begin{array}{l}\text { Governança Metropolitana na América Latina: um panorama } \\
\text { das experiências contemporâneas sob uma mirada } \\
\text { comparativa }\end{array}$ \\
\hline Organizadores(as) & $\begin{array}{l}\text { Marco Aurélio Costa } \\
\text { Lizandro Lui } \\
\text { Sara Tavares Rebello }\end{array}$ \\
\hline Volume & 4 \\
\hline Série & Governança Metropolitana na América Latina \\
\hline Cidade & Rio de Janeiro \\
\hline Editora & Instituto de Pesquisa Econômica Aplicada (Ipea) \\
\hline Ano & 2021 \\
\hline Edição & $1 a$ \\
\hline ISBN & $978-65-5635-017-2$ \\
\hline DOI & DOI: http://dx.doi.org/10.38116/978-65-5635-017-2 \\
\hline
\end{tabular}

(C) Instituto de Pesquisa Econômica Aplicada - ipea`2020

As publicações do Ipea estão disponíveis para download gratuito nos formatos PDF (todas)

e EPUB (livros e periódicos). Acesse: http://www.ipea.gov.br/portal/publicacoes

As opiniões emitidas nesta publicação são de exclusiva e inteira responsabilidade dos autores, não exprimindo, necessariamente, o ponto de vista do Instituto de Pesquisa Econômica Aplicada ou do Ministério da Economia. É permitida a reprodução deste texto e dos dados nele contidos, desde que citada a fonte. Reproduções para fins comerciais são proibidas. 


\title{
VENEZUELA: DA DESCENTRALIZAÇÃO IMPERFEITA À CENTRALIZAÇÃO ABSOLUTA'
}

\author{
Ignacio Cardona² \\ Luis Schloeter ${ }^{3}$ \\ Carlos Urdaneta Troconis ${ }^{4}$
}

\section{INTRODUÇÃO}

A Venezuela é um Estado federal nos termos definidos na Constituição Nacional e organizada em 23 estados, um distrito da capital e agências federais. Os $916.445 \mathrm{~km}^{2}$ de seu território estáo organizados em 335 municípios. Segundo o Instituto Nacional de Estadística (INE), a projeção da população nacional em 30 de junho de 2019 era de 32.219 .521 habitantes. ${ }^{5}$ A população urbana excede $90 \%$; especificamente, mais de $75 \%$ da população nacional reside em cidades com 100 mil habitantes ou mais.

Este capítulo procura fazer uma análise histórica do processo de descentralização, com ênfase na governança metropolitana, no caso venezuelano. É um processo historicamente marcado entre a estrutura legal que define a República como Estado federal versus o poder onipotente do Estado centralizado.

O capítulo começará resgatando antecedentes que buscam enquadrar o processo de descentralizaçáo na tradiçáo ideológica venezuelana desde a formação do período colonial e explicar os primeiros passos para a descentralização em meados da década de 1980 .

Posteriormente, explicaremos o que chamamos de descentralização imperfeita, um processo progressivo de transferência de recursos e competências para os governos locais do poder central e que tem sua fase culminante na

1. DOI: http://dx.doi.org/10.38116/978-65-5635-017-2cap4

2. Arquiteto e urbanista; pesquisador na Harvard Graduate School of Design; e consultor no âmbito do Programa Executivo de Cooperação Cepal//pea. E-mail: <iac@arepa.info>.

3. Economista urbano; mestre em desenvolvimento econômico urbano pela University College London; e mestre em planejamento urbano pela New York University. E-mail: <luisschloeter@gmail.com>.

4. Urbanista da Universidad Simón Bolívar; mestre em desenvolvimiento urbano pelo El Colegio de México; e professor investigador do Departamento de Planejamento Urbano da Universidad Simón Bolívar. E-mail:<carlosurdaneta@usb.ve>. 5. Disponível em: <http://www.ine.gov.ve/index.php?option=com_content\&view=category\&id=98\&ltemid=51http:// www.ine.gov.ve/index.php?option=com_content\&view=category\&id=98\&ltemid=51>. 
Constituição da República Bolivariana da Venezuela de 1999 e na Lei Orgânica do Poder Público Municipal de 2006. Alguns críticos explicam esse processo de descentralização, ainda considerado imperfeito, mas que define uma arquitetura institucional em que o município é a unidade política de classificação institucional na busca por uma democracia participativa.

Em seguida, explica-se um processo progressivo de recentralização institucional e desmontagem do aparato institucional descentralizado. Esse pode ser resumido em três níveis: i) nível estadual, com a designação de uma figura não constitucional chamada chefe de governo, com espaços geográficos delimitados sob controle direto do Executivo nacional que trabalha paralelamente à administração dos estados federados estabelecidos no marco legal e constitucional; ii) nível municipal, com a criação do Poder Comunal e a transferência obrigatória de recursos e competências municipais para as chamadas comunas com relação direta com a vice-presidência da República, processo que constitui um sistema de gestão e planejamento local fora do aparato constitucional coordenado por grupos e funcionários não eleitos; e iii) nível metropolitano, com uma série de decisóes graduais que acabaram eliminando os governos metropolitanos existentes em 2017.

A análise do marco regulatório dessas decisóes nos leva a concluir a óbvia debilitação do sistema democrático venezuelano a partir do desmantelamento de sua descentralização institucional.

\section{ANTECEDENTES}

\subsection{A emergência de um poder nacional todo-poderoso}

Historicamente, na Venezuela, o Executivo nacional tem desempenhado um papel dominante na determinação dos destinos e níveis de governança do país, incluindo o nível metropolitano. Sua supremacia quase absoluta ocorreu mesmo antes do nascimento da nação como Estado independente, na era colonial, por meio do monopólio comercial na troca com a coroa espanhola (Lieuwen, 1965). Esse processo atingiu níveis extremos quando a Venezuela se tornou um país petroleiro de propulsão única a partir da década de 1920 (Hellinger, 1991). Esse Estado, como intermediário de todas as trocas socioeconômicas, o torna um organismo todo-poderoso centralizado.

Sob esses preceitos ideológicos herdados da tradição colonial, a Venezuela foi estruturada com base na definição de estratégias técnico-normativas e padronização do poder central e na aplicação e gestão no nível municipal desses regulamentos.

Foi assim que, no período da ditadura militar, entre 1953 e 1958, a regiáo metropolitana (RM) de Caracas registrou uma forte intervenção do poder central expressa no fortalecimento da capital, com a construção de grandes infraestruturas 
e serviços. A consolidação da capital, aliada a um processo de terceirização da economia decorrente da dependência econômica (Gilbert, 1998), principalmente da renda do petróleo, acabou por intensificar a migração do campo para a cidade, consolidando as capitais de estado, e especialmente Caracas, como verdadeiros centros metropolitanos. Entre 1936 e 1950, a chamada população urbana da Venezuela saltou de $28,9 \%$ da populaçáo nacional para $47,9 \%$ (atingindo $62,5 \%$ em 1961); o aumento populacional do Distrito Federal - território federal no qual a cidade de Caracas está sediada - foi significativo, com um aumento de 36,3\% entre 1936 e 1941, e 97,4\% do aumento da população entre 1941 e 1950 (Venezuela, 1962). Desse modo, o território metropolitano da Venezuela já era irreversível.

Em 1958, a ditadura caiu e o período democrático se iniciou. Em 1961, foi aprovada uma Constituição que permaneceria em vigor até 1999. García-Guadilla (2009) enfatiza como, a partir desse período, é consolidado o caráter rentista e al tamente centralizado do modelo de desenvolvimento econômico, político e de planejamento na Venezuela. Tal processo veio sendo observado desde o período colonial e acabou se aprofundando com a transformaçáo do país em um Estado conectado ao sistema capitalista mundial por meio da renda do petróleo gerenciada diretamente pelo nível central. A partir de 1958, os governos democráticos assumiram uma estratégia política que visava desacelerar a migração do campo para a cidade, diminuindo substancialmente os investimentos públicos nas capitais, especialmente em Caracas, buscando a descentralização da população e das atividades no território (Negrón, 1995). Mesmo assim, a construção de grandes obras rodoviárias e complexos habitacionais e de serviços (educacionais, assistenciais e recreativos), bem como o transporte em massa de pessoas (metrô de Caracas), continuou no período democrático.

O sistema democrático pouco emergente, com um alto nível de instabilidade política, cria um ambiente sociopolítico ameaçado. Além disso, a centralização histórica do poder administrativo notou a ausência de capacidades nos estados e municípios tradicionais para assumir competências (Delfino, 2005).

\subsection{Primeiros passos para a descentralização}

A uniformidade dos planos locais administrados a partir do poder central foi gerando, paulatina, mas constantemente, uma demanda político-cidadá pela regionalizaçáo nas estratégias de planejamento. Vale ressaltar que a Constituição de 1961, em seu art. 25, reafirma os municípios como unidades políticas primárias e autônomas da arquitetura institucional da república, em um poder público organizado em três níveis: nacional, estadual e municipal.

É assim que uma descentralizaçáo institucional começa a ser gerada gradualmente, sem consolidar uma descentralização político-administrativa. 
Começam a ser desconcentrados o poder público por meio de vários institutos autônomos, fundaçóes, fundos, sociedades e empresas de Estado (Urbina Mendoza, 2019), que criaram muitos escritórios regionais, administrados, contudo, a partir do poder central. É gerada então uma burocratizaçâo excessiva do aparato do todo-poderoso estatal, com uma complexa distorção regulatória e institucional cada vez mais ineficaz, com alguns estados federados enfraquecidos com a crescente perda de importância, tanto no nível econômico quanto no político e administrativo (Delfino, 2005).

É assim que o modelo do rentista-petroleiro acaba no fim dos anos 1980 . Uma intensa crise econômica que devastou toda a América Latina marca o colapso do Estado todo-poderoso e centralizado. A redução do gasto público do poder nacional nas cidades foi claramente evidenciada na redução da atividade pública em questôes como habitação de interesse social e no subsídio de serviços públicos. Esse fenômeno aumentou os efeitos socioespaciais negativos do modelo de desenvolvimento, como a intensificação dos níveis de desigualdade territorial com setores mais dependentes do Estado central, que acabam sendo menos atendidos. Isso também resulta na redução dos níveis de governança geral e, principalmente, da governança urbana nos territórios metropolitanos (García-Guadilla, 2009). Assim, grupos políticos regionais que demandam atenção por parte do Estado emergiram gradualmente.

Por fim, a combinação entre esse clima político a favor da descentralização e a crise econômica e suas implicaçôes na redução orçamentária iniciada em meados de 1982 (Urbina Mendoza, 2019) torna obrigatório o rearranjo da imensa burocracia centralizada para dar lugar a uma administração descentralizada, mais eficiente e mais próxima das necessidades do cidadáo.

\section{ROTA DE DESCENTRALIZAÇÃO IMPERFEITA}

\subsection{0 início da descentralização na Venezuela}

Foi assim que, em 1984, foi criada a Comissão Presidencial de Reforma do Estado (Comisión Presidencial para la Reforma del Estado - Copre), que, com base em uma série de consultas com diferentes atores do mundo político e da sociedade civil (Carvajal, 2008), termina por definir diretrizes sobre descentralização política e administrativa, juntamente com uma necessária reorganização do governo central (Delfino, 2005). Entre essas recomendaçóes se destacam a de fazer a eleição direta de governadores e prefeitos, e a transferência de poderes nacionais para os governos locais.

Consequentemente, 1989 foi um marco no processo de descentralização da Venezuela, com o surgimento de três instrumentos normativos icônicos no 
campo da descentralização. Primeiro, a Lei de Eleição e Remoção de Governadores Estaduais, ${ }^{6}$ que regulamentaria a eleição direta de governadores estaduais até a data indicada diretamente pelo Executivo nacional. Segundo, a reforma da Lei Orgânica do Regime Municipal,7 originalmente promulgada em 1978, que destacou a criação da figura do prefeito como chefe do Poder Executivo municipal. Até aquele momento, o Poder Executivo do ente municipal era exercido pelo Poder Legislativo. Terceiro, a inovadora Lei Orgânica de Descentralização, Delimitação e Transferência de Poder Público, ${ }^{8}$ cujos dispositivos favoreceram significativamente o processo de descentralização, com uma arquitetura estadual mais focada nos municípios da própria República (Urbina Mendoza, 2019). Nela se regulariza a transferência progressiva do poder central para as regióes dos serviços públicos e recursos financeiros em matéria de planejamento, coordenação e promoção do desenvolvimento integral regional e local. Nesse andaime institucional foi sendo criada uma descentralização que vai além de sua consideração como técnica organizacional para aos poucos se transformar em uma política de Estado (Delfino, 2005).

Assim, pela primeira vez, em 3 de dezembro de 1989, a eleição direta de prefeitos e governadores ocorreu na Venezuela, marcando um novo marco na história da descentralização venezuelana. Entre muitos de seus efeitos positivos, esse processo resultou no aparecimento de novas lideranças políticas em nível nacional, na exigência por respostas particulares para as próprias identidades regionais e no surgimento impetuoso das peculiaridades culturais das regiōes no cenário nacional. As vantagens desse processo de descentralização começaram a se mostrar de forma muito clara.

\subsection{Conflito do governo local versus gestão metropolitana}

Contudo, juntamente com as vantagens da descentralização, seus conflitos também surgem, como é o caso da relação entre governos locais e gestão metropolitana. É emblemático o caso particular da capital da República, que acaba desenvolvendo um processo de fragmentação de municípios com base no princípio da proximidade (Paiva, 2001), a partir do qual o Metropolitano de Caracas passa de dois a cinco municípios conurbados, que compóem a primeira coroa metropolitana. Assim, começa a surgir entáo um conflito baseado na governança entre uma visão vicinal e a abordagem das necessidades das comunidades locais, geralmente gerenciadas no nível municipal versus a visão metropolitana de consolidar as necessidades de articulação técnica em escalas maiores.

6. Publicada na Gaceta Oficial, extraordinário, № 4.086, de 14 de abril de 1989.

7. Publicada na Gaceta Oficial, o 4.109, de 15 de junho de 1989.

8. Publicada na Gaceta Oficial, ํo 4.153, de 28 de dezembro de 1989. 
Buscando enfrentar esse conflito entre o olhar local e o metropolitano, em 1993 foi instituído o Regulamento Parcial no 6 da Lei Orgânica sobre Descentralização, Delimitação e Transferência de Poderes do Poder Público. ${ }^{9}$ O regulamento foi criado pelo Conselho de Governos da Regiāo Metropolitana de Caracas como órgão de cooperação, conciliação e coordenação das atividades de governos de diferentes níveis para a realização de obras e a prestação de serviços comuns à RM e o planejamento do desenvolvimento urbano da RM de Caracas. Tal institucionalidade era simplesmente um espaço de defesa política e tributária das autoridades municipais perante o governo central (Paiva, 2001), mas que já assinalava a necessidade de governança metropolitana. Vale ressaltar que outros dois municípios da segunda coroa metropolitana foram incluídos nesse conselho, o que evidenciou o desejo de entender a natureza metropolitana de sua gestáo.

\subsection{Reflexões da descentralização entre 1989 e 1999}

Os resultados positivos e os conflitos desse incipiente processo de descentralização iniciado em 1989 foram múltiplos. Em termos de planejamento, a Lei Orgânica do Planejamento Urbano ${ }^{10}$ estabeleceu os planos de desenvolvimento urbano (Projecto de Desenvolvimento Urbano e Local - PDUL) como a ferramenta fundamental e protagonista da gestâo urbana, e cujo regulamento ${ }^{11}$ estabeleceria como competência exclusiva dos municípios a participação do cidadão em consultas urbanas.

Em relação à transferência de recursos para os municípios, duas leis adicionais permitiram aumentar a distribuição de renda entre as regióes. Primeiro, os regulamentos legais para a criação do Fundo Intergovernamental para a Descentralização (Fides). ${ }^{12}$ Em seguida, a Lei de Alocações Econômicas Especiais (LAEE), ${ }^{13}$ que procurou descentralizar o regime de alocaçóes econômicas especiais derivadas de minas e hidrocarbonetos, destinando $70 \%$ para as entidades territoriais onde os depósitos estavam localizados e os 30\% restantes para o "modo de compensação" (Delfino, 2005) entre as entidades territoriais em cujo território esses depósitos não são encontrados.

No que se refere à participação cidadã, o Regulamento no $1^{14}$ da Lei Orgânica do Regime Municipal ${ }^{15}$ atribuiu um papel relevante aos conselhos paroquiais e associaçóes de vizinhança como representantes da sociedade civil e interlocutores da administração municipal, embora esse regulamento tenha limitado o

9. Publicada na Gaceta Oficial, extraordinário, № 35.301, de 21 de setembro de 1993.

10. Publicada na Gaceta Oficial, extraordinário, no 33.868, de 16 de dezembro de 1987.

11. Publicada na Gaceta Oficial, o 34.678, de 19 de março de 1991.

12. Originalmente criado pelo Decreto-Lei no 3.265 , de 25 de novembro de 1993, revogado e novamente promulgado e publicado na Gaceta Oficial, extraordinário, № 5.132, de 3 de janeiro de 1997.

13. Publicada na Gaceta Oficial, ำ 36.110, de 18 de dezembro de 1996.

14. Publicada na Gaceta Oficial, extraordinário, no 5.398, de 26 de outubro de 1999.

15. Publicada na Gaceta Oficial, ํo 4.109, de 15 de junho de 1989. 
desenvolvimento de uma consciência de bairro, definindo o que García-Guadilla (2009) chamou de corporativismo da vida do bairro que promove a segregação urbana em defesa dos interesses dos condomínios ${ }^{16}$ sobre a integração urbana.

\subsection{Descentralização na Constituição de 1999}

Em 1999, a Constituição da República Bolivariana da Venezuela, ainda em vigor, estabeleceu a República como uma sociedade democrática, participativa e protagonista. $\mathrm{O}$ art. $4^{\circ}$ declara a República como um Estado federal descentralizado e o art. 16 - o primeiro da divisão político-territorial nacional - especifica a garantia da autonomia municipal e da descentralização político-administrativa.

Seguindo a tradiçẫo constitucional venezuelana que remonta ao nascimento da República (Brewer-Carías, 2003), o art. 136 da Constituição de 1999 prevê a distribuição de poder em três níveis: poder municipal, poder estatal e poder nacional, consolidando o município como instituição político-territorial constitucional.

Do ponto de vista da descentralizaçăo, Delfino (2005) ressalta que as seguintes características podem ser mencionadas na Constituição de 1999:

- a preeminência do poder público nacional, principalmente em relação aos recursos financeiros e fiscais; a afetação da autonomia dos Estados para o ditado de sua própria Constituição e de sua organização como poder público, por meio da publicação de uma lei nacional de cumprimento obrigatório; o tratamento de competências concorrentes entre os três níveis de poder público por meio de uma lei nacional; e a transformação para uma lei nacional no caso de alguns poderes exclusivos dos Estados;

- a consagração de uma Assembleia Nacional unicameral que substitui o bicameralismo ${ }^{17}$ contemplado nas constituiçôes anteriores, com as quais deixa de existir a representaçáo igualitária de entidades federais;

- a ausência de definição da participação dos Estados na vontade federal, na reforma da Constituição e na formação de leis é considerada uma exigência constitutiva da forma federativa; e

- a violação da autonomia dos Estados também é evidenciada quando não contempla o consentimento da entidade federal para a segregação de parte de seu território para a criação de um território federal.

16. Na Venezuela, o condomínio é a figura legal e organizacional que administra edifícios multifamiliares. Seu uso corporativista, nesse caso, passa a significar a visão estreita em que os problemas urbanos podem ser abordados por alguns atores locais.

17. A Câmara do Senado foi eliminada pela Constituição de 1999. 
A Constituição de 1999 também introduziu inovaçōes importantes na área da descentralização, entre as quais: i) a possibilidade de gerar diferenciação entre os municípios, a fim de superar a uniformidade no planejamento entre regióes que foram as principais críticas à municipalização do país desde a época da Copre; ii) a criação de outras entidades locais, além da paróquia municipal tradicional, entre as quais o Distrito Metropolitano; iii) a inauguração da figura do Conselho Local de Planejamento, ${ }^{18}$ que inclui representantes das organizações de bairro, que visa elevar os níveis de participação do cidadão nos processos de descentralização; e iv) a incorporaçáo enfática e sistemática da participação do cidadão na gestão pública, em seu controle e avaliação.

\subsection{Distrito Metropolitano na Constituição de 1999}

Conforme dito, a Constituição da República Bolivariana da Venezuela de 1999 indicou que o poder público municipal é exercido pelos municípios, as principais unidades políticas da arquitetura do estado. Mas também o art. 169 estabelece que esse poder pode ser exercido por outras entidades locais, entre as quais os distritos metropolitanos (arts. 171 e 172).

O Distrito Metropolitano é, portanto, considerado uma entidade territorial local, em uma governança municipal de dois níveis (metropolitana e municipal), cujas autoridades seriam eleitas e sua institucionalidade gozaria de autonomia financeira e clareza na definição de seus poderes. No entanto, a gestão metropolitana eventualmente deslocaria a administração local ou regional em determinadas funçóes e escalas (Paiva, 2001), gerando conflitos de competência que nunca seriam resolvidos.

Embora a Constituição de 1999, segundo seu art. 4º , seja governada pelos princípios de "integridade territorial, cooperação, solidariedade, concorrência e corresponsabilidade", essa concorrência obriga que se faça um acordo entre os diferentes poderes para alcançar uma responsabilidade conjunta coordenada entre diferentes atores, a fim de evitar sobreposiçóes negativas nas competências entre eles, e também uma clareza na definição de competências que não foram resolvidas.

Como veremos mais adiante, os conflitos de competências entre o nível metropolitano e o municipal foram evidenciados pela criação da Lei Especial sobre o Regime do Distrito Metropolitano de Caracas, ${ }^{19}$ quando, a pedido de um apelo à interpretação do primeiro prefeito metropolitano perante o Supremo Tribunal de Justiça (STJ), ${ }^{20}$ sua Câmara Constitucional determinou a existência

18. Lei dos Conselhos Locais de Planejamento, publicada no Diário Oficial da União, no 37.463, de 12 de junho de 2002. 
de dois níveis de governança: um macrocorrespondente ao nível metropolitano e outro microcorrespondente à própria escala municipal, mas sem esclarecer as competências ou responsabilidades para cada um desses dois níveis. ${ }^{21}$

\subsection{A Lei Orgânica do Poder Público Municipal}

Em 2006, a Lei Orgânica do Poder Público Municipal ${ }^{22}$ se torna o marco legal mais importante que consolida o município da Venezuela ${ }^{23} \mathrm{em}$ seu processo de descentralização. Seu art. 1ำ determina que sua função é garantir "o exercício efetivo da participaçáo protagonista do povo nos assuntos da vida local, de acordo com os valores da democracia participativa, corresponsabilidade social, planejamento, descentralização e transferência para comunidades organizadas e grupos de bairro". ${ }^{24}$ Desse modo, repetindo o que está descrito no art. 168 da Constituiçấo de 1999, o art. 2º da Lei Orgânica do Poder Público Municipal reafirma o município como a principal unidade política da República que goza de personalidade jurídica e exerce seus poderes autonomamente. Em seguida, indica que as açóes dos municípios devem incorporar, de maneira eficaz, suficiente e oportuna, a participação do cidadão nos diferentes papéis da ação municipal, incluindo suas definiçóes, execuçóes, controle e gerenciamento de resultados.

Claramente, assume-se a importância de uma descentralização que busca aproximar a gestão municipal do cidadão, a fim de aprofundar a democracia participativa. Nesse sentido, Brewer-Carías (2015) destaca que, com essa arquitetura de poder, o município implica a existência de uma comunidade com vínculos permanentes de vizinhança e enfatiza como a lei estabelece como condição necessária a existência de "uma população firmemente estabelecida em um determinado território com ligaçóes permanentes à vizinhança" (art. 10.1). A relação simbiótica entre vizinhos e governo municipal é estabelecida e promovida na lei na busca de um município que aponte para a descentralização. A relação direta entre a participação da comunidade, por meio de conselhos paroquiais e associaçôes de bairro organizadas em determinado território, e a governança municipal descentralizada é estabelecida constitucional e legalmente.

21. Como veremos, essa indefinição persistiria até a eliminação de todos os governos metropolitanos na Venezuela em 2017.

22. Publicada na Gaceta Oficial, extraordinário, ㄲo 5.806, de 10 de abril de 2006.

23. Lembre-se de que, na estrutura legal venezuelana, os distritos metropolitanos são considerados "entidades locais" de natureza municipal. Portanto, essa lei também se aplicará ao nível metropolitano do governo municipal.

24. Essa lei é emendada em 2010 (publicada no Diário Oficial da República Bolivariana da Venezuela, extraordinário, no 6.015, de 28 de dezembro de 2010). Na referida reforma, o art. 10 "comunidades organizadas e grupos de vizinhança" será alterado para "comunidades organizadas e comunas em seu status especial de entidade local, como acontece com outras organizações do Poder Popular", em um ajuste à arquitetura. 


\subsection{As competências municipais da Lei Orgânica do Poder Público Municipal}

A Lei Orgânica do Poder Público Municipal, que regulamenta as disposições da Constituição da República Bolivariana da Venezuela em relação à descentralização municipal, refere-se no seu Título II aos municípios e outras entidades locais. Lembremos que, no art. 19, a referida lei estabelece que, além dos municípios, os distritos metropolitanos são entidades territoriais locais. A partir daí, a Lei Orgânica do Poder Público Municipal regula, com seus arts. 52 a 74, os poderes dos municípios em seus dois níveis, municipal e metropolitano.

Também é verdade que a Lei Orgânica do Poder Público Municipal resulta nos poderes da Constituiçẫo de 1999 (art. 178) do município e, em seu art. 56, lista o que chama de poderes próprios, concomitantes, também descentralizados e delegados dos municípios. São eles: i) o governo e a administração dos interesses próprios da vida local; e ii) a gestão dos assuntos que a Constituição e as leis nacionais lhes confiam, especialmente nos assuntos relacionados à vida local e à organização e promoção do desenvolvimento econômico e social. São, ainda, especificadas nove competências específicas: i) planejamento territorial e urbano e suas técnicas associadas, como serviço de cadastro ou moradia de interesse social; ii) estradas urbanas e trânsito de veículos e pessoas nas estradas; iii) espetáculos públicos e publicidade comercial; iv) proteção ambiental; v) saúde e atenção primária à saúde; vi) serviços de água potável, eletricidade e gás doméstico, de iluminação pública, disposição de esgoto, matadouros, cemitérios, serviços funerários, suprimentos e mercados; vii) justiça da paz; viii) organização e operação da administração pública municipal; e, finalmente, ix) os demais relacionados à vida local e aos que lhe são atribuídos pela Constituição, além das leis nacionais e estaduais.

Essas definições de competência acabam enfatizando uma arquitetura institucional propensa à descentralização. No entanto, a definição entre o nível macrometropolitano e o nível micromunicipal, como mencionamos anteriormente, permaneceria sem solução. Isso afetaria a clareza das responsabilidades do governo metropolitano.

\subsection{Uma descentralização imperfeita}

Como vimos, a Venezuela tem sido um Estado altamente centralizado, embora sua tradição constitucional tenha organizado a distribuição de poder em vários níveis: poder municipal, poder estatal e poder nacional. A condição nacional de um Estado economicamente dependente da renda do petróleo deu ao poder nacional uma supremacia onipotente. Assim, a crise latino-americana da década de 1980 e o indício de esgotamento do modelo rentista abriram caminho para a descentralização com caráter seminal na criação da Copre em 1984, que tem um 
marco significativo em 1989, quando, entre outras coisas, ocorrem as primeiras eleições diretas de prefeitos e governadores.

A Constituição da República da Venezuela em 1999 acabou consolidando um espírito que, do nosso ponto de vista, foi gerado historicamente, principalmente quando consolida o município como unidade política primária e autônoma dentro da organizaçáo nacional (art. 25), buscando uma nova arquitetura ao definir uma República democrática, participativa e líder em seus princípios fundamentais. Em seguida, a Lei Orgânica do Regime Municipal (2006, reformada em 2010) regula os municípios e abre a possibilidade de criação de distritos metropolitanos quando dois ou mais municípios mantêm relaçóes econômicas, sociais e físicas que conferem ao conjunto urbano as características que merecem uma visão metropolitana de seus sistemas.

Neste último, surge imediatamente o antagonismo entre a participação do bairro e a coordenação metropolitana. Embora as necessidades das comunidades, em seu caráter extremamente local, tenham se tornado na Venezuela uma variável fundamental na democratização dos processos institucionais por meio da participação dos cidadãos, também é verdade que a coordenação metropolitana acaba sendo um fator fundamental para fornecer uma solução técnica para os problemas municipais, intensificar o planejamento coordenado e aumentar a eficiência na administração e prestação de serviços públicos. Daí a importância de um trabalho coordenado entre os diferentes níveis de governo estabelecidos na arquitetura do Estado, do poder do cidadão ao poder nacional, mas a partir do poder municipal, metropolitano, quando necessário, do Estado, para articular soluções integradas entre diferentes territórios.

A construção de um desenho institucional do Estado que permita esses níveis de interação tem sido um processo histórico que vem gerando uma mudança gradual nas instituiçóes políticas do Estado, a fim de reduzir a predominância, às vezes padronizada, do poder nacional.

Embora tenha havido algumas falhas na descentralização - especialmente a falta de clareza do nível metropolitano como entidade articuladora das necessidades locais em maior escala -, também é verdade que estava sendo construída uma arquitetura democrática do Estado que buscava vincular a participação do cidadão com diferentes níveis de governo.

Em suma, pelo menos até a criação da Lei Orgânica do Regime Municipal, em 2006, a Venezuela seguia o caminho de uma descentralização imperfeita. Em seguida, começou um processo progressivo de recentes centralizaçóes institucionais que acabou afetando todos os níveis da arquitetura do Estado. Buscando explicar esse processo em toda a sua complexidade, uma vez que esses níveis de governo implicam diferentes graus de concorrência, dividiremos 
essa transição para a recente centralização em três níveis: municipal, estadual e metropolitano, com ênfase especial em suas implicaçóes nesse último nível.

\section{TRANSIÇÃO PARA A RECENTRALIZAÇÃO: NÍVEL MUNICIPAL}

Como explicado aqui anteriormente, a Constituição de 1999 estabelece que a Venezuela é um Estado federal descentralizado, estruturado em um sistema de distribuiçẫo vertical do poder público em três níveis: poder municipal, poder estadual e poder nacional, cada um com um governo eleito, descentralizado e alternativo. No entanto, entre 2006 e 2017, foi realizado na Venezuela um processo de redistribuição de poderes e de transferência de recursos entre os diferentes níveis de governo que alteraram o equilíbrio de poder entre os poderes públicos. Essa reconfiguração institucional substituiu a política de descentralização por uma política de recente centralização e desconcentração de competências.

Durante esse período, foram aprovadas leis que levaram à desmunicipalização da Venezuela, diminuindo a autonomia e as capacidades dos governos locais. As competências da participação cidadã, planejamento e gestão pública foram transferidas em grande parte para um sistema institucional comunitário, liderado pelo Executivo nacional (Brewer-Carías, 2007). Paralelamente, as leis foram reformuladas e aprovadas para reorientar os fundos de transferência intergovernamentais para organizações comunitárias destacadas dos governos municipais e estaduais. Essas políticas, na prática, diminuíram o poder dos prefeitos e governadores e deram mais responsabilidade às organizaçóes comunitárias que não têm representação democrática (Ríos, Ortega e Scrofina, 2012).

Como havíamos dito, na Venezuela, o município foi concebido como uma instituiçẫo política territorial de nível constitucional. Os municípios foram constituídos como a principal unidade política da organização nacional, desfrutando de sua própria personalidade jurídica e autonomia. Entretanto, durante o período de recente centralização, os municípios perderam o poder de promover a participação cidadã. Por sua vez, a autonomia municipal no planejamento foi prejudicada pela reestruturação dos conselhos locais de planejamento público, e uma estrutura legal foi estabelecida para incentivar a transferência de competências para as organizaçóes comunitárias. Ao mesmo tempo, as administrações municipais receberam gradualmente menos contribuiçôes financeiras do governo central, reduzindo sua capacidade de gestão local. Em vez disso, um sistema chamado Poder Popular foi estabelecido após a aprovação de uma série de leis orgânicas. ${ }^{25} \mathrm{O}$ processo começou após a entrada em vigor da Lei dos Conselhos Comunitários, de 2006. ${ }^{26}$

25. Em 2007, o governo nacional propôs uma reforma constitucional que buscava estabelecer o Estado comum. A proposta foi rejeitada na consulta popular de 7 de dezembro de 2007. No entanto, o governo central aprovou as leis do Poder Comunitário por meio de decretos com a patente e força de lei por meio de uma Lei de Habilitação.

26. Publicada na Gaceta Oficial, ํ55.806, extraordinário, de 10 de abril de 2006. 


\subsection{Participação do cidadão: das reuniões de paróquia aos conselhos comunitários}

O município na Venezuela era a entidade política territorial convocada para efetivar a participação cidadã. Os municípios foram planejados como espaços primários para a participação dos cidadáos no planejamento e na gestáo pública. Destaca-se daí, entre os poderes autônomos dos municípios, o de impulsionar e promover a participação cidadã de maneira efetiva, suficiente e oportuna. ${ }^{27}$

Os mecanismos para promover a participação do cidadão no território municipal já haviam sido desenvolvidos pela Lei do Regime Municipal (1989). ${ }^{28}$ Os municípios dispunham dos conselhos paroquiais e das associaçóes de bairro para incorporar as comunidades organizadas na gestáo local. Ambas as instituiçóes possuíam instrumentos de coordenação com as autoridades municipais eleitas, ${ }^{29}$ uma vez que os municípios são compostos por uma administração pública e um órgáo legislativo cujos representantes - o prefeito e os conselheiros - devem ser eleitos democraticamente por sufrágio universal, direto e secreto, a cada quatro anos. Isso estabeleceu uma representatividade democrática da população por meio do sufrágio.

\subsubsection{Conselhos paroquiais e associações de bairro}

Assim, duas instituiçóes permitiram a incorporação de comunidades organizadas na gestão municipal: conselhos paroquiais e associaçôes de bairro.

Por um lado, os conselhos paroquiais administravam uma unidade territorial submunicipal chamada paróquia. As paróquias eram demarcações intramunicipais, criadas para descentralizar a administração municipal, promover a participação do cidadáo e a melhor prestação de serviços públicos locais. ${ }^{30}$ Os conselhos paroquiais eram compostos por membros eleitos por voto direto, secreto e universal entre os moradores de seus respectivos campos. Suas atribuiçóes eram de natureza gerencial, consultiva e de avaliação. A lei especificou que as juntas paroquiais levariam ao prefeito as aspiraçóes da comunidade relacionadas aos serviços locais, para as quais estabeleceriam os meios de consulta e comunicaçáo regular com as comunidades e organizaçóes sociais. Dessa forma, as paróquias foram configuradas como entidades auxiliares do governo municipal e dos órgãos locais de participação, através das quais os vizinhos colaborariam na gestão dos assuntos comunitários.

27. Lei da Reforma Parcial da Lei Orgânica do Poder Público Municipal (2006).

28. Publicada na Gaceta Oficial, no 4.109, de 15 de junho de 1989.

29. Os municípios são compostos por uma administração pública (prefeito) e um órgão legislativo (Conselho Municipal). Tanto o prefeito quanto os conselheiros devem ser eleitos democraticamente por sufrágio universal, direto e secreto, a cada quatro anos.

30. Ley Orgánica del Régimen Municipal. Disponível em: <http://oas.org/juridico/spanish/ven_res48.pdf>. 
Por outro lado, também foi regulamentada a criação de associaçóes de bairro. ${ }^{31} \mathrm{~A}$ lei estabeleceu que os municípios deveriam favorecer o desenvolvimento de associaçóes de bairro que seriam usadas para defender interesses coletivos. Da mesma forma, os municípios devem fornecer a essas associaçóes as informaçóes mais abrangentes sobre suas atividades, promovendo sua participação na gestão municipal.

Ambas as instâncias de participação tiveram que ser fortalecidas no âmbito da política de descentralização da Constituição de 1999 para garantir um diálogo construtivo e uma participação inclusiva orientada a resultados, preservando a institucionalidade entre os diferentes níveis do poder público, a representatividade democrática e o planejamento territorial no nível subnacional. Entretanto, os conselhos paroquiais e as associaçóes de bairro foram eliminados com a entrada em vigor da Lei dos Conselhos Comunitários (2006), da Lei Orgânica do Poder Público Municipal (2006) e da Lei Orgânica dos Conselhos de Planejamento Local (2010). ${ }^{32}$ Essas instâncias foram substituídas pelos conselhos comunitários, que careciam de institucionalidade democrática e dependiam do governo central, dissociando-se da gestão subnacional (Brewer-Carías, 2007).

\subsubsection{Conselhos comunais}

Foi assim que, em 2006, foi aprovada a Lei dos Conselhos Comunitários, estabelecendo as assembleias cidadâs como a instância principal para o exercício do poder, a participação e a exigência de um papel popular. O objetivo da lei seria desenvolver a conformação das instâncias de participação e seu funcionamento para a formulação, execução e avaliaçáo de políticas públicas. ${ }^{33}$

Os conselhos comunais foram novamente regulados em 2009 com a aprovação da Lei Orgânica dos Conselhos Comunaiss ${ }^{34}$ e em 2010 através da Lei Orgânica do Poder Popular, onde foram definidos como instâncias de participação, articulação e integração entre os cidadãos com a ideia permitir que as pessoas organizadas exerçam o governo comunitário e gerenciem diretamente políticas públicas e projetos. ${ }^{35}$

Em relação aos mecanismos de formação e funcionamento dos conselhos comunais, eles são constituídos por iniciativa das próprias comunidades, sem uma eleição universal, direta e secreta, que permita a participação de todos os membros da comunidade. Mesmo em relação àqueles não diretamente envolvidos com a

31. Ley Orgánica del Régimen Municipal. Disponível em: <http://oas.org/juridico/spanish/ven_res48.pdf>.

32. Publicada na Gaceta Oficial, no 6.017, extraordinário, de 30 de dezembro de 2010.

33. Ley de los Consejos Comunales, de 10 de abril de 2006.

34. Publicada na Gaceta Oficial, № 39.335, de 28 de dezembro de 2009.

35. Ley Orgánica del Poder Popular, publicada na Gaceta Oficial, ํo 6.011, extraordinário, de 21 de dezembro de 2010. 
comunidade, a iniciativa de formar um conselho é provisória. Para a formação do Conselho Comunal, a lei estabelece que essa equipe de promotores, composta por indivíduos da comunidade, convoque uma primeira Assembleia Cidadã com a participação mínima de $10 \%$ dos habitantes da comunidade maiores de 15 anos. Nessa primeira assembleia, chamada de Assembleia Constituinte da Comunidade, os porta-vozes do Conselho da Comunidade são eleitos pela primeira vez.

Entre as principais funçôes dos conselhos comunitários estão as aprovaçôes de seu escopo geográfico, de planos e projetos comunitários, bem como do pedido de transferência de serviços. $\mathrm{O}$ modelo de gestáo anterior era realizado, de acordo com a lei de 2009, com o acompanhamento do Ministério do Poder Popular, ao qual os poderes foram atribuídos em termos de participação cidadã. Dessa maneira, os governos municipais perderiam autonomia sobre seu território e sua capacidade de promover a participação cidadã. Em vez disso, a participação do cidadão se torna uma função coordenada entre o governo nacional e os conselhos comunais.

\subsubsection{Planejamento e gestão municipal do desenvolvimento comunal}

Como visto, a Constituição venezuelana estabelece os poderes dos diferentes níveis do poder público: poder público nacional, estadual e municipal. Essa distribuição de poderes torna possível diferenciar os poderes atribuídos aos órgãos dos três níveis territoriais e os assuntos sobre os quais os poderes são exercidos em cada nível (Brewer-Carías, 2003). Em nenhum momento o nível territorial comunal é definido na Constituiçáo. Apesar disso, o arcabouço legal desenvolvido desde 2006 transfere poderes dos municípios para entidades denominadas Poder Popular, organizaçóes comunitárias que não têm representantes eleitos pelo direito de voto, mas porta-vozes selecionados que dependem do governo central (Hernández, 2017). Essas organizaçôes foram finalmente transferidas primeiramente para os poderes de planejamento, depois para os serviços públicos.

\section{Recentralização no planejamento}

A lei venezuelana atribui aos municípios a competência para desenvolver e adotar planos de desenvolvimento, entre os quais se destacam o Plano de Desenvolvimento Municipal e o Plano de Desenvolvimento Urbano Local. ${ }^{36} \mathrm{O}$ primeiro foi definido como um instrumento que reflete as diretrizes de governança de cada um dos municípios para o período de gestão de quatro anos. O segundo é uma ferramenta de planejamento que deve regular, entre outros aspectos, o uso da

36. Lei Orgânica do Poder Público Municipal, publicada no Diário Oficial, no 6.015, extraordinário, de 28 de dezembro de 2010. 
terra de acordo com a Lei Orgânica para o Planejamento do Território de 1983, a Lei Orgânica do Planejamento Urbano de 1987 e os planos nacionais. ${ }^{37}$

Por isso, a Lei Orgânica do Poder Público Municipal de 2006 reconheceu, entre os poderes diretos do prefeito, a formulaçáo desses instrumentos, o Plano de Desenvolvimento Municipal e o Plano de Desenvolvimento Urbano Local. De fato, a Lei Orgânica do Planejamento estabeleceu que os planos, as políticas, os programas e os projetos dos órgãos e das entidades municipais devem acabar sendo articulados ao Plano de Desenvolvimento Municipal elaborado pelo prefeito como representante máximo do poder municipal.

O mecanismo disponível para os municípios exercerem sua competência em questóes de planejamento local seriam os conselhos locais de planejamento público, criados a partir da Lei de Planejamento Orgânico de $2001^{38}$ e da Lei dos Conselhos Locais de Planejamento Público de 2002. ${ }^{39}$ De acordo com os regulamentos aprovados entre 2001 e 2002, esses conselhos locais de planejamento público são órgãos responsáveis pelo planejamento integral do governo local, com o objetivo de alcançar a integração das comunidades organizadas.

Os conselhos locais de planejamento público seriam compostos pelo prefeito, pelos conselheiros, pelas juntas paroquiais e pelos representantes de organizaçóes de bairro ou povos indígenas. A representaçáo da sociedade civil nos conselhos locais de planejamento público ocorreria por meio de um processo eleitoral. Desse modo, seria garantida a participação do cidadáo no planejamento municipal, levando em consideração todos os espaços geográficos do município, mediante a incorporação de representantes das juntas paroquiais e associaçôes de bairro.

De acordo com o exposto, os prefeitos teriam autonomia para formular os planos de desenvolvimento municipal e os planos de desenvolvimento urbano, mas também a responsabilidade de fazê-lo com o apoio dos conselhos locais de planejamento público. De qualquer forma, destaca-se que os conselhos públicos locais de planejamento funcionam como um órgão do poder público municipal, a fim de garantir a cobertura territorial e a participação do cidadão nos processos de planejamento. No entanto, durante o período de recente centralizaçáo, os municípios perderam autonomia para formular seus planos municipais.

Em 2010, por meio de uma lei que concedeu ao Executivo nacional o poder de aprovar decretos com hierarquia e força de lei, o governo central

37. Ambas as leis seriam revogadas pela Lei Orgânica para Planejamento e Gerenciamento da Gestão da Terra (2005). No entanto, embora a lei tenha sido sancionada e aprovada, ela nunca entrou em vigor e, portanto, não revogou as leis. 38. Publicada na Gaceta Oficial, no 5.554, de 13 de novembro de 2001.

39. A Lei dos Conselhos Locais de Planejamento Público foi aprovada em 2002 e reformulada em 2010 e 2015. Sua versão mais recente foi publicada no Diário Oficial, no 6.184, extraordinário, de 3 de junho de 2015. 
aprovou a Lei Orgânica do Planejamento Público e Popular, ${ }^{40}$ revogando a Lei do Planejamento Orgânico de 2001 (Brewer-Carías, 2015). Nessa lei, foi estabelecido o Sistema Nacional de Planejamento, que, entre seus objetivos, procuraria contribuir para a otimização dos processos de definição, formulação, execução e avaliação de políticas públicas. A lei determinaria também que o Sistema Nacional de Planejamento fosse integrado pelo Conselho do Governo Federal, pelos conselhos estaduais de planejamento e coordenação de políticas públicas, pelos conselhos locais de planejamento público, pelos conselhos de planejamento comunitário e pelos conselhos comunitários.

Da mesma forma, essa lei instituiu que os conselhos locais de planejamento público seriam os órgãos encarregados de elaborar o Plano de Desenvolvimento Municipal e os demais planos municipais de acordo com as diretrizes do Plano Nacional de Desenvolvimento Econômico e Social. Isso foi realizado paralelamente à reformulação da Lei dos Conselhos Locais de Planejamento Público de 2010 nesse caso, reestruturando sua conformação para que eles também fossem integrados pelos conselhos comunais. Ambas as reformas passaram a competência efetiva do desenho do Plano de Desenvolvimento Municipal aos conselhos comunais, em coordenação com o governo central.

\section{Rumo à gestão comunitária de serviços públicos}

Em 2010, o governo central também aprovou a Lei Orgânica do Conselho do Governo Federal ${ }^{41}$ para firmar diretrizes nos processos de transferência dos poderes das entidades territoriais para as organizaçôes do Poder Popular. A lei enfatiza a natureza vinculativa para as entidades territoriais das diretrizes estabelecidas pelo Conselho do Governo Federal. Da mesma forma, indica a transferência de poderes para o Poder Popular como um mecanismo para alcançar seu fortalecimento. Consequentemente, é criado um órgão cuja responsabilidade seria promover a transferência de competências e recursos para entidades territoriais criadas na Lei do Poder Popular.

Em 2012, para regulamentar o processo de transferência de competências, o governo nacional aprovou um decreto com classificação, valor e força de Lei Orgânica para a Gestão da Concorrência e outros poderes do Poder Popular. ${ }^{42}$ De acordo com a lei, o objetivo é a transferência da gestáo e administração de serviços, atividades, bens e recursos, do poder público nacional e das entidades político-territoriais, para a sociedade civil organizada. Para esse fim,

40. Publicada na Gaceta Oficial, no 6.184, extraordinário, de 3 de junho de 2015.

41. Publicada na Gaceta Oficial, № 39.382, de 9 de março de 2010.

42. Publicado no Diário Oficial, no 6.079, extraordinário, de 15 de junho de 2012. Esse decreto seria modificado por outro da mesma categoria, publicado no Diário Oficial da República, o 40.540, em 13 de novembro de 2014, que não modifica o que é referido nesta seção. 
a lei estabeleceria um mandato para a criação do Plano de Transferência para estabelecer os princípios, as normas, os procedimentos e os mecanismos que permitam a realização dessa transferência.

Dois aspectos que se destacam no Plano de Transferência é que sua formulação é obrigatória, o que implica que os órgãos do poder público devem propor a transferência de poderes para o Poder Popular. Além disso, o Plano de Transferência seria realizado de acordo com as diretrizes definidas pelo Conselho do Governo Federal e em coordenação com o Ministério do Poder Popular com jurisdição sobre as comunidades, que também tem a aprovação do referido plano (Hernández, 2010). Com efeito, a nova lei daria ao governo central poderes para transferir poderes para os conselhos da comunidade.

Esse decreto-lei enumera os serviços sujeitos à transferência, como: atenção primária à saúde; manutenção de centros educacionais; administração de programas sociais; proteção ambiental e coleta de resíduos sólidos; e prestação de serviços públicos. No entanto, a lista não é exaustiva. Com a aprovação do decreto-lei, diferentes municípios do país transferiram serviços para os conselhos comunitários, como a manutenção de praças e parques, iluminação pública e coleta de resíduos sólidos.

\subsubsection{Transferências subnacionais: a redistribuição de recursos entre municípios e conselhos comunitários}

Como explicamos anteriormente, o sistema de descentralização da Venezuela, antes da recente centralização, estabeleceu vários instrumentos de transferência intergovernamental. Os governos subnacionais receberam cerca de $70 \%$ de sua renda por meio da coparticipação e outras transferências do governo central (Fretes Cibils e Ter-Minassian, 2015). As transferências vieram principalmente do Acordo Constitucional, do Fides, criado em 1993, e da LAEE, de 1996. Esses fundos destinavam-se a permitir que os governos subnacionais cumprissem seus poderes legais e constitucionais.

A partir da recente centralização, essas leis foram modificadas para reorientar os fundos de transferência intergovernamentais para beneficiar governos subnacionais politicamente alinhados com o nível central e financiar os conselhos comunitários, de acordo com o mandato das leis do Poder Popular (Fretes Cibils e Ter-Minassian, 2015). A principal mudança foi a eliminação do Fides por meio da Lei Especial de Liquidação do Fundo Intergovernamental de Descentralização, promulgada em 2010. Em vez disso, foi aprovada a Lei do Conselho do Governo Federal, por meio da qual foi criado o Fundo de Compensação Interterritorial (FCI). Embora previsto na Constituição de 1999, o FCI foi estabelecido com a aprovação da Lei do Conselho Federal em 2010. 
A administração da FCI depende do Conselho do Governo Federal, que decide sobre a alocação de recursos para estados, municípios e organizações do Poder Popular. Cabe apontar que o Conselho do Governo Federal é composto pelo vice-presidente executivo, ministros, governadores e prefeitos de cada estado e pela sociedade civil organizada representada pelos porta-vozes das organizaçóes do Poder Popular. Essa estrutura implica o controle do Executivo nacional sobre a atribuição de transferências a entidades subnacionais.

A partir de 2011, o Conselho do Governo Federal decidiu modificar as transferências para os governos subnacionais da FCI da seguinte forma: $35 \%$ para os conselhos comunitários, $37 \%$ para os estados e $28 \%$ para os municípios. Dessa forma, alterou significativamente a renda de governos estaduais e municipais para financiar conselhos comunitários, afetando ainda mais a capacidade subnacional na prestação de serviços domésticos básicos. Como resultado, em 2011, os municípios de dez estados do país começaram a receber menos recursos para transferências do que as entidades do Poder Popular (Salas-Bourgoin, 2016).

\section{A TRANSIÇÃO PARA RECENTRALIZAÇÃO: NÍVEL ESTADUAL}

A Constituiçáo de 1999 estabeleceu os poderes exclusivos dos estados no âmbito da política de descentralização da Venezuela. No entanto, a partir do processo de centralização, em 2006, o governo nacional modificou a estrutura legal para transferir poderes dos governos estaduais, especialmente no que diz respeito a estradas e rodovias nacionais, além de portos e aeroportos. No entanto, para minar a autonomia dos governos estaduais, o governo central estabeleceu os órgãos desconcentrados das regiōes estratégicas de desenvolvimento integral como autoridades paralelas, designadas pelo vice-presidente da República.

Conforme aqui explicado, de acordo com a Constituição de 1999, os estados tinham poderes exclusivos relacionados aos serviços de infraestrutura. Eles foram atribuídos à "conservação, administração e uso de estradas e rodovias nacionais, portos e aeroportos, em coordenação com o poder nacional" (Brewer-Carías, 2018). O anterior correspondia à Lei Orgânica sobre Descentralização, Delimitação e Transferência de Poderes do Poder Público de 1989 e à Constituição Nacional (Brewer-Carías, 2018). No entanto, por meio de uma interpretação constitucional, a Câmara Constitucional do STJ modificou a norma e transferiu esses poderes ao Executivo nacional.

Em 2007, a Procuradoria-Geral da República interpôs um recurso de interpretação perante o STJ. A solicitação buscou esclarecer a incerteza jurídica no que diz respeito à coordenação com o Executivo nacional da competência exclusiva atribuída aos estados para conservar, gerenciar e tirar proveito das estradas e rodovias nacionais, além de portos e aeroportos. O STJ no Julgamento 
no 565 , de 15 de abril de 2008, decidiu que a referida competência não é exclusiva dos estados: o legislador nacional deve estabelecer por meio de leis básicas que regulam os poderes concorrentes a cada ente. O STJ conclui sua decisão instando a Assembleia Nacional a revisar e modificar as leis relacionadas à conservação, à administração e ao uso de estradas e rodovias nacionais, portos e aeroportos. Dessa forma, o STJ modificou a Constituição, alterando a política de descentralização estabelecida em 1999.

Posteriormente, em 2009, a Assembleia Nacional reformou a Lei de Descentralização, Delimitação e Transferência de Competências, ${ }^{43}$ incorporando duas mudanças significativas. Primeiro, estabeleceu que o Executivo nacional pode reverter, por razōes estratégicas ou por conveniência, a transferência dos poderes concedidos aos estados. Segundo, que o Executivo nacional pode decretar a intervenção de bens e benefícios dos serviços públicos.

Como resultado, a Lei de Portos $^{44}$ e a Aviação Civil ${ }^{45}$ foram reformuladas, permitindo ao Executivo nacional assumir o controle da infraestrutura portuária e aeroportuária. Consequentemente, o Executivo nacional estabeleceu a Comissáo de Reversão por meio da qual transferiu a infraestrutura portuária e aeroportuária dos estados de Nueva Esparta, Zulia, Carabobo e Vargas para o governo nacional (Sabatino, 2009). Em relação às estradas, o governo nacional eliminou a cobrança nos postos de pedágio, privando os estados de uma atribuição constitucional (Sánchez Melean, 2018).

\subsection{A administração nacional paralela: os organismos desconcentrados das regiões estratégicas do desenvolvimento integral}

Outra decisão que afetou a estrutura de autonomia dos governos regionais foi a criação dos órgãos desconcentrados das regiôes estratégicas de desenvolvimento integral (Regiones Estratégicas de Desarrollo Integral - Redi). Eles foram criados por resolução do Executivo nacional e regulamentados após a reforma da Lei Orgânica da Administração Pública e a aprovação da Lei de Regionalização Integral para o Desenvolvimento Socioprodutivo da Pátria (Brewer-Carías, 2019).

O decreto estabelece as Redi como

espaços geográficos delimitados nos quais o Executivo nacional executará a coordenação, o planejamento, a execução e o monitoramento das políticas públicas nacionais, levando em consideração as particularidades de cada regiáo; com o objetivo de desconcentração territorial da gestão governamental. ${ }^{46}$

43. Publicada na Gaceta Oficial, o 39.419, de 17 de março de 2009.

44. Publicada na Gaceta Oficial, ำ 39.140, de 17 de março de 2009.

45. Publicada na Gaceta Oficial, no 39.140, de 17 de março de 2009.

46. Disponivel em: <http://extwprlegs1.fao.org/docs/pdf/ven125152.pdf>. 
Seis Redi foram estabelecidas em todo o país, cobrindo pelo menos um estado cada.

As Redi são responsáveis pelas autoridades regionais, que têm dependências em cada estado e são responsáveis pelas delegações estaduais, cujos coordenadores são nomeados pelo vice-presidente da República. Com a reformulaçáo da Lei da Administração Pública, em 2014, ${ }^{47}$ as delegaçóes estaduais foram renomeadas como "chefes de governo". Esses chefes de governo exercerão suas funções no território do estado designado. Dessa maneira, eles foram concebidos como intermediários entre o governo central e as organizaçóes do Poder Popular, ao exigir a responsabilidade de "manter a coordenação do Executivo nacional com as comunidades organizadas". ${ }^{48}$

Da mesma forma, estabelece o decreto que as Redi receberão recursos alocados por meio de transferências do Fundo de Compensação Territorial. Desse modo, as Redi seriam elegíveis para receber transferências intergovernamentais que, em princípio, deveriam ter como objetivo apenas fortalecer os governos constitucionais subnacionais, que possuem autoridades democraticamente eleitas.

Em conclusão, as autoridades regionais e os delegados estaduais são órgãos descentralizados da administração pública nacional e são instâncias paralelas a governos estaduais cujo objetivo é manter o controle do centro sobre ações de políticas públicas nas regiōes.

\section{A TRANSIÇÃO PARA RECENTRALIZAÇÃO: NÍVEL METROPOLITANO}

\subsection{Antecedentes sobre as Caracas metropolitanas}

Caracas é a capital e primeira cidade da Venezuela. Está localizada no centro norte da Venezuela e da América do Sul (mapa 1). Seu Plano Regulador de 1950 já reconhece o fenômeno metropolitano, quando a cidade (localizada em uma entidade municipal chamada Libertador, no Distrito Federal) começou a ultrapassar suas fronteiras tradicionais sobre o município de Sucre, no estado vizinho Miranda (Negrón, 1995) (mapa 2). A RM de Caracas também foi definida para fins estatísticos, censitários e administrativos. Na década de 1970, é criada a RM de Caracas, a fim de coordenar as açóes dos órgãos públicos. 
MAPA 1

Caracas metropolitanas: localização no contexto nacional

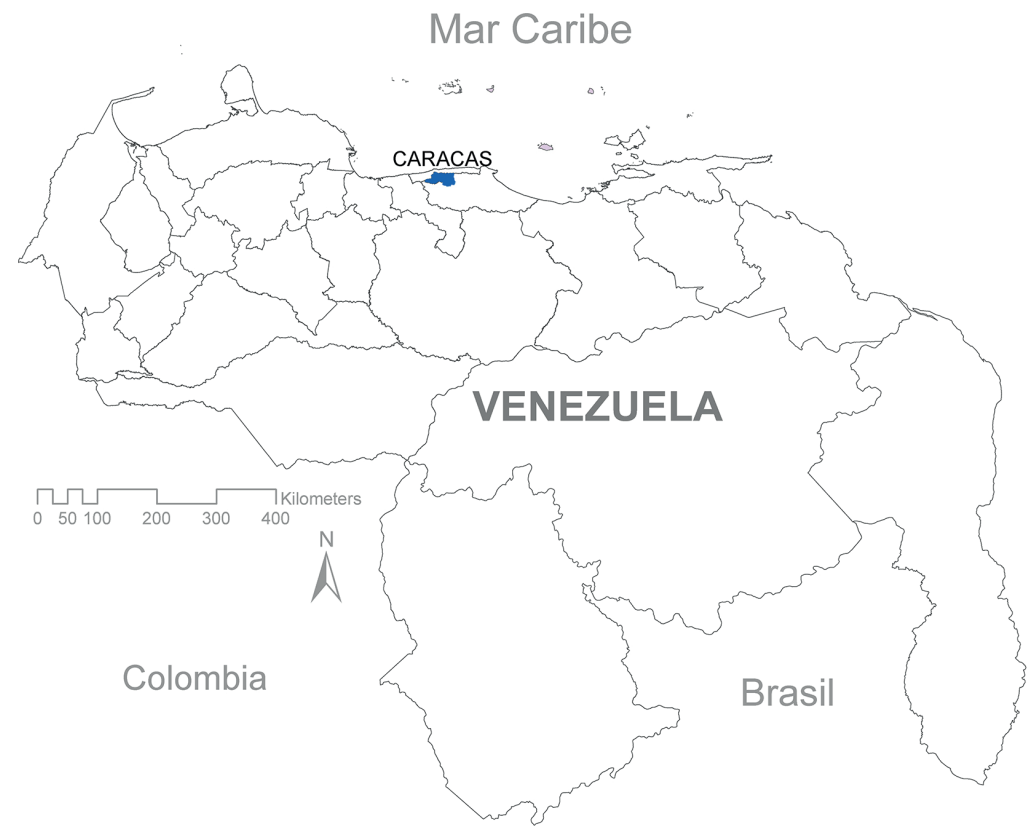

Fonte: Urdaneta-Troconis (2013).

MAPA 2

Caracas metropolitanas: início do processo metropolitano (municípios)
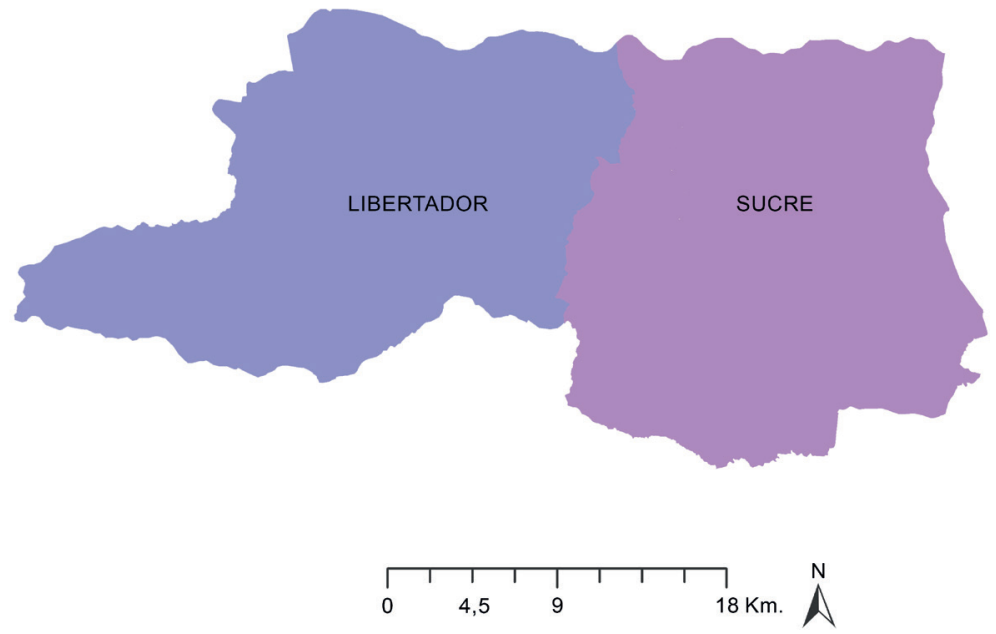

Fonte: Urdaneta-Troconis (2013). 
Naquela década e na próxima (1970-1980), sua RM foi configurada. Caracas é o centro do principal conglomerado urbano de um sistema de cidades de diferentes tamanhos e com diferentes níveis de interação e função. Os componentes da RM de Caracas $^{49}$ (mapa 3) e Grande Caracas (outros doze municípios do estado Miranda e La Guaira, onde residem outros 2,123 milhóes de pessoas) ${ }^{50}$ (figura 1).

\section{MAPA 3 \\ Zona metropolitana de Caracas (municípios)}
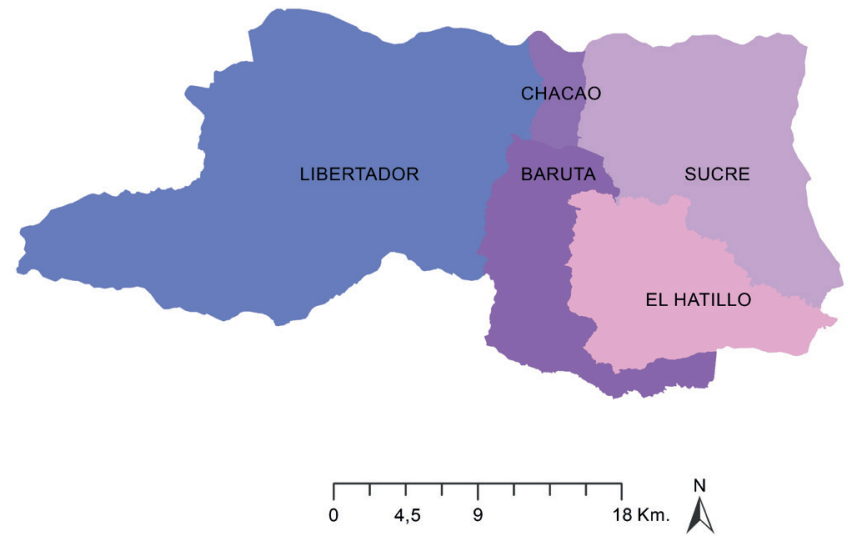

Fonte: Urdaneta-Troconis (2013)

FIGURA 1

RM de Caracas

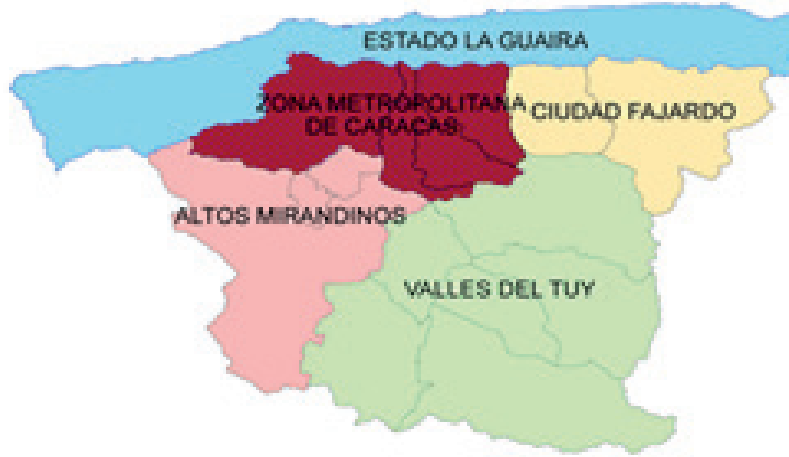

Fonte: Urdaneta-Troconis (2013).

Obs.: Figura reproduzida em baixa resolução e cujos leiaute e textos não puderam ser padronizados e revisados em virtude das condições técnicas dos originais (nota do Editorial).

49. A cidade histórica de Caracas, no município de Libertador e no município de Sucre e suas três divisões nos novos municípios de Baruta, Chacao e El Hatillo, do estado de Miranda contam com uma população de 3,347 milhões de pessoas em 2019. 50. Por sua vez, eles compreendem sub-regiões metropolitanas: Altos Mirandinos, a sudeste da Zona Metropolitana de Caracas, é composto pelo município capital do estado de Miranda, Guaicaipuro, e pelos municípios Carrizal e Los Salias; Ciudad Fajardo, composta pelos municípios Plaza e Zamora, a leste da área metropolitana de Caracas; Vales de Tuy, que corresponde aos municípios de Rojas, Independência, Lander, Paz Castillo, Bolívar e Urdaneta, ao sul da área metropolitana de Caracas; e La Guaira, com seu único município de Vargas, localizado ao norte da área metropolitana de Caracas. 
O tamanho da população atingida pela Caracas metropolitana - bem como sua fragmentação política e institucional, ${ }^{51}$ e sua crescente complexidade das relaçóes sociais, econômicas e da dinâmica urbana, além do fato de ser a primeira cidade do país e sua capital - exigiu uma nova institucionalidade democrática de escala metropolitana que responderia a esses processos, para os quais são necessárias competências claramente definidas, bem como a capacidade de gerar e dispor dos recursos necessários para tais fins.

\subsection{Distrito Metropolitano de Caracas}

A Constituição Nacional de 1999 contempla a figura de um governo metropolitano de Caracas. Em fevereiro de 2000, a Assembleia Nacional Constituinte ditou a Lei Especial sobre o Regime do Distrito Metropolitano de Caracas, ${ }^{52}$ cujo escopo é a área metropolitana nascida em resposta a ela, mas não a Grande Caracas do ano 2000, segundo a qual a realidade regional metropolitana não é levada em consideração na estrutura institucional.

Essa nova entidade político-territorial foi organizada em um sistema de governo municipal em dois níveis: o metropolitano, formado por um órgáo executivo (presidido pelo prefeito metropolitano), um órgáo legislativo (o Conselho Metropolitano); e o municipal, formado por um órgão executivo (presidido pelo prefeito) e um órgão legislativo (o conselho municipal) em cada um dos cinco municípios que compóem o Distrito Metropolitano de Caracas. Foi instituído que o prefeito metropolitano e os conselheiros metropolitanos seriam eleitos por voto popular, universal, direto e secreto. ${ }^{53}$ Considerou-se, portanto, que o modelo organizacional metropolitano consolidado é adotado da seguinte forma: uma entidade supramunicipal única, que conta com autoridades eleitas pelos cidadãos dos municípios que o compóem, com autonomia financeira, poderes e funçóes específicos (Delfino, 2002).

O Distrito Metropolitano de Caracas existiu desde a sua criação em 2000 até 2009 e, durante esse período, o prefeito e os conselheiros metropolitanos foram eleitos. Para os períodos de 2000-2004 e 2004-2008, os prefeitos e a maioria dos conselheiros foram eleitos na mesma linha política do governo nacional. Contrariamente, no período de 2008-2012, os políticos da oposição assumiram o poder.

51. As autoridades executivas com poderes que afetam a RM de Caracas são: o presidente da República; o vice-presidente da República; os ministros do gabinete; o governador do Distrito Federal; o governador do estado de Miranda; os cinco prefeitos dos municípios metropolitanos; os membros de órgãos legislativos - Assembleia Nacional, Conselho Legislativo de Miranda e 49 conselheiros municipais -; bem como um grande número de autoridades executivas dos vários órgãos do governo (nacional, estadual, Distrito Federal e municípios metropolitanos).

52. Publicada na Gaceta Oficial, ํo 36.906, de 8 de março de 2000.

53. Ley Especial sobre el Régimen del Distrito Metropolitano de Caracas, art. 6 . 
O Distrito Metropolitano de Caracas foi concebido como herdeiro do Distrito Federal ${ }^{54}$ e, portanto, seus poderes foram determinados com base nos exercidos por essa entidade político-territorial, mas também nos de um município, dado seu caráter de governo municipal em dois níveis. Isso produziu uma reação imediata tanto nas primeiras autoridades metropolitanas eleitas quanto nas autoridades estaduais e municipais de Miranda da RM, uma vez que se considerou que o Distrito Metropolitano de Caracas invadiu as competências municipais.

O Conselho do Governo Metropolitano era um órgão superior de consultoria e de assessoria do prefeito metropolitano, presidido por este e também integrado pelos prefeitos dos municípios metropolitanos, ${ }^{55}$ sem indicar a periodicidade para sua convocação, coisa que se contemplou com a subsequente Portaria de Funcionamento do Conselho do Governo Metropolitano de Caracas, ${ }^{56}$ que regula seu desempenho, estabelecendo suas funções e a periodicidade de sua convocação. Esse conselho reuniu-se em poucas ocasiōes, nem sempre com a presença de todos os prefeitos, e não teve grande importância no período de existência do Distrito Metropolitano de Caracas, uma vez que, nessa instância, sofreu a mesma desconfiança e relutância que havia entre os prefeitos da cidade e os municípios metropolitanos do próprio Distrito Metropolitano de Caracas. Isso ocorreu não apenas por se tratar de um processo conflituoso que atrapalhava a ordem institucional preexistente, mas também devido à suposta invasão de poderes municipais, à polarização política existente no país e à forma estabelecida pela Lei para o financiamento do Distrito Metropolitano de Caracas.

Recorreu-se ao STJ que solicitasse a interpretação desses poderes e sua demarcação entre as diferentes entidades territoriais. O julgamento explicativo de competências do Distrito Metropolitano de Caracas emanado da Câmara Constitucional do STJ ${ }^{57}$ estabeleceu, entre outros elementos, que o Distrito Metropolitano deve abordar o nível macro dos poderes municipais, ou seja, sobre o metropolitano, que definiria o conselho através das ordenanças metropolitanas e que, enquanto isso não acontecesse, cada município continuaria a governar e administrar essas áreas. Em outras palavras, o princípio da legalidade é questionado, bem como sua eficácia, uma vez que a governança metropolitana não é alcançada apenas pela emissão de leis locais, mas sim dentro da estrutura da implementação de uma nova institucionalidade, o que implica árduo processo de reconhecimento, negociação e legitimação.

54. De acordo com a Lei de Transição do Distrito Federal para o Distrito Metropolitano de Caracas, publicada no Diário Oficial, ำ 37.006, de 8 de agosto de 2000.

55. Lei especial sobre o regime do Distrito Metropolitano de Caracas, arts. 9o e 10.

56. Publicado no Diário Oficial do Distrito Metropolitano de Caracas, em 27 de novembro de 2001.

57. Sentença no 1.563 da Sala Constitucional do STJ, em 13 de dezembro de 2000. 
Embora o STJ tenha exigido que o nível metropolitano desenvolvesse sua própria competência, ${ }^{58}$ um espaço político-administrativo e sua própria institucionalidade, não é menos verdadeiro que esse esforço foi dificultado por uma visão recentralizadora do poder nacional, ao não permitir a descentralização de competências de nível metropolitano evidentes, como a de planejamento urbano, transporte metropolitano ou redes de serviços (eletricidade, aqueduto, esgoto, gás doméstico, disposição final de resíduos e resíduos). Em outras palavras, o nível nacional - e também o nível municipal - pretendia que o nível metropolitano de Caracas se definisse, sem se comprometer a colaborar nessa definiçẫo.

Diante de um cenário competitivo e complicado, a administração dos dois primeiros prefeitos foi marcada por uma continuidade com a administração do antigo Distrito Federal, expresso nessa área (igual ao município de Libertador, mas, de qualquer forma, não nos municípios metropolitanos do estado de Miranda), para a qual a cultura organizacional, civil, orçamentária e financeira da antiga governança do Distrito Federal contribuiu como base para criar a institucionalidade metropolitana de maneira peculiar, uma vez que, além disso, tinha restriçóes para gerenciar recursos para toda a RM, como será visto a seguir.

Entre as receitas alocadas pela lei de criação do Distrito Metropolitano de Caracas, estavam dois tipos cuja execução deveria ser realizada exclusivamente no município de Libertador: o situado constitucional e o subsídio de capital, constituindo uma situação administrativa sui generis na Venezuela, na qual os princípios de unidade do Tesouro e a execução de recursos em todo o escopo territorial de uma entidade governamental foram violados.

Adicionalmente, a autonomia financeira dessa entidade ficou seriamente comprometida, uma vez que se apontava que $10 \%$ da renda própria efetivamente coletada por cada município metropolitano no exercício fiscal imediatamente anterior era destinada ao Tesouro metropolitano. Tornou-se a renda mais complicada de arrecadar, pois, sem considerar o fenômeno inflacionário, foi necessário desenvolver uma grande capacidade de estimar essa renda e, sobretudo, inseri-la nas contas do Distrito Metropolitano de Caracas, uma vez que os municípios não tinham obrigação de entregá-la em determinado momento, que poderia ter sido, como de fato era, quase um ano após sua coleta, no ano anterior. Essa renda metropolitana foi vista como confisco da renda municipal pelos prefeitos dos municípios metropolitanos e a tornou uma poderosa arma de negociação política com o nível metropolitano, atrasando e condicionando sua entrega sob a condiçáo de investir em seus respectivos municípios. Foi um

58. Evidenciado no julgamento explicativo de competências do Distrito Metropolitano de Caracas emanado da Câmara Constitucional do STJ, nำ 1.563, de 13 de dezembro de 2000. 
verdadeiro cavalo de Troia contra a implementação e o desenvolvimento da institucionalidade metropolitana.

\subsection{Rumo à dissolução do Distrito Metropolitano de Caracas}

Uma vez eleito, em novembro de 2008, o terceiro prefeito metropolitano de Caracas, em oposição ao partido do governo nacional, a Assembleia Nacional promulgou a Lei Especial de Organização e Regime do Distrito da Capital, ${ }^{59} \mathrm{em}$ abril de 2009. Seu escopo era o antigo Distrito Federal, igual ao território do município de Libertador, onde está localizada a cidade histórica.

Essa lei eliminou os poderes substantivos metropolitanos dos serviços públicos (aqueduto, eletricidade, transporte) do Distrito Metropolitano. Consequentemente, é possível concluir que, para o poder nacional, o monopólio desses serviços deve ser gerenciado pelo Executivo nacional, sem muito sucesso, a propósito, a julgar pela atual crise de serviços públicos na cidade e no país. É assim que se constitui uma expressão clara da visão centralista.

Embora a aprovação dessa lei tenha gerado controvérsia, ${ }^{60}$ não é menos verdade que a aprovação da lei especial de criação do Distrito Capital é um mandato constitucional que não foi cumprido até aquele momento, apesar de que nove anos se passaram desde que o Distrito Metropolitano de Caracas assumiu seus poderes. Em outras palavras, a necessidade de criar o referido Distrito Capital está em questão porque, embora os prefeitos tenham sido afetados pelo poder nacional, não havia necessidade de criá-lo, e outra figura poderia exercer sua função. Contudo, mais do que ignorar o prefeito opositor do Distrito Metropolitano, ${ }^{61}$ pode-se afirmar que, na realidade, a Assembleia Nacional ignorou o mandato popular concedido pelo povo tanto à pessoa que ocupava esse cargo quanto àqueles que foram eleitos como conselheiros metropolitanos para gerenciar o governo metropolitano com os poderes que o Distrito Metropolitano tinha quando foram eleitos. Não se esperou que o período constitucional terminasse para que a dissoluçáo do Distrito Capital tivesse efeito e não houvesse referendo (aprovação, consultoria) para ouvir do povo sua opiniáo sobre a eliminação do Distrito Metropolitano de Caracas e sobre a criação de uma nova entidade para substituí-lo. ${ }^{62}$ Também não foram realizadas eleiçóes para que, com uma nova

59. Publicada na Gaceta Oficial, ํo 39.156, de 13 de abril de 2009.

60. Duas posições são identificadas: argumenta-se que o Distrito Capital foi criado para extrair poderes do Distrito Metropolitano de Caracas e ignorar o prefeito Ledezma. Outra posição indica que sua criação está contemplada na Constituição e que, portanto, um mandato constitucional foi cumprido. 0 que esta última posição não aborda é a comparação de competências de uma e de outra.

61. De fato, a sétima disposição da Lei Especial do Regime Municipal em Dois Níveis da Região Metropolitana de Caracas indica que, até o final do período constitucional, a nomeação de prefeito do Distrito Metropolitano de Caracas continuaria sendo mantida.

62. Conforme declarado, a consulta popular estabelecida no art. 171 da Constituição Nacional. 
entidade político-territorial com outros poderes, o povo escolhesse as autoridades da nova entidade metropolitana. Trata-se de uma maneira curiosa de prosseguir com um discurso de democracia participativa e protagonista.

Contudo, pode-se duvidar da legalidade da transferência de bens e recursos de uma entidade que já não existia mais - o Distrito Federal - para o Distrito Capital, com o argumento de que este último era herdeiro do primeiro, porque na Lei de Transição do Distrito Federal para o Distrito Metropolitano de Caracas não se estabeleceu nenhuma disposição a esse respeito. Obviamente, essa transferência de bens e recursos afetou gravemente a capacidade de gestáo metropolitana.

O processo de dissolução do Distrito Metropolitano de Caracas foi gradual, com duração de menos de um ano, o que consistiu em privá-lo de poderes derivados do Distrito Federal para culminar, cinco meses depois, em sua eliminação formal no mesmo ato legal de criação da entidade político-territorial que a substitui, a RM de Caracas. ${ }^{63}$ Sua organizaçáo e seu escopo foram semelhantes aos do Distrito Metropolitano $^{64}$ de Caracas. Note-se que, em termos formais, a Constituição Nacional reconhece apenas uma área metropolitana para indicar que pode levar à criação de um Distrito Metropolitano, que é a única figura governamental desse tipo de metrópole considerada na Carta Magna e no sistema legal venezuelano. Portanto, a denominação dada à entidade que substitui o Distrito Metropolitano de Caracas é, no mínimo, inapropriada.

Tanto para a criação do Distrito Metropolitano de Caracas quanto da área metropolitana de Caracas, os órgãos legislativos não cumpriram o disposto nos arts. 170 e 171 da Constituição, ${ }^{65}$ como a consulta popular necessária para decidir sobre a vinculação dos municípios metropolitanos com a entidade metropolitana. O governo municipal também é mantido em dois níveis, o que implica relaçóes de suprassubordinação entre as partes envolvidas (nível metropolitano/municipal) e não coordenação e cooperação, no sentido em que Delfino (2002) o desenvolve. Atribuídos como competência fundamental, planejamento e coordenação ${ }^{66} \mathrm{em}$ assuntos ${ }^{67}$ que podem ser catalogados como metropolitanos, os resultados de sua gestão seriam apreciados a longo prazo. ${ }^{68} \mathrm{~A}$ maioria, se não todos, não tinha a viabilidade política e até administrativa a ser desenvolvida.

63. Lei Especial do Regime Municipal de Dois Níveis da Região Metropolitana de Caracas, publicada no Diário Oficial, ำ 39.276, de 10 de outubro de 2009.

64. Ver arts. 170 e 171 da Constituição Nacional. Disponíveis em: <http://mhov.com.ve/wp-content/uploads/2014/08/ Constitucion-de-la-Republica-Bolivariana-de-Venezuela.pdf $>$.

65. Publicada na Gaceta Oficial, no 5.908, extraordinário, de 19 de fevereiro de 2000. Disponível em: <http://mhov. com.ve/wp-content/uploads/2014/08/Constitucion-de-la-Republica-Bolivariana-de-Venezuela.pdf>.

66. Considera-se uma condição para a gestão metropolitana, mas não suficiente.

67. Lei Especial do Regime Municipal de Dois Níveis da Região Metropolitana de Caracas, art. 5‥

68. Planejamento e coordenação em planejamento urbano e urbano; proteção ambiental e saneamento ambiental; promoção e gestão de associações entre municípios metropolitanos e prestação de assistência técnica a municípios e comunidades (art. 5o da Lei Especial do Regime Municipal de Dois Níveis da Região Metropolitana de Caracas). 
A lei sobre a criação da área metropolitana de Caracas eliminou a situação constitucional que, dada a existência da unidade político-territorial constituída pelo Distrito Capital, foi concedida a este último. As receitas das províncias de Miranda e do Distrito Capital, bem como as dos municípios metropolitanos, constituíram parte substancial das receitas metropolitanas, entregues ao tesouro metropolitano sem periodicidade predeterminada e, novamente, também condicionadas ao fluxo de caixa dos fornecedores, quanto ao condicionamento frequente de sua entrega ao investimento no âmbito da referida entidade, comprometendo a autonomia financeira da administraçáo metropolitana.

O Conselho do Governo Metropolitano foi eliminado da lei que cria a área metropolitana de Caracas. Embora tenha sido uma instância inoperante sob a existência do Distrito Metropolitano de Caracas, é incomum que, sob o desenho institucional dado a essa nova unidade político-territorial, a existência dessa instância seja justificada pelo chefe do Executivo de cada município metropolitano, o principal responsável pela administração dos municípios metropolitanos. Tão necessária foi uma instância como essa que, de fato, foi formada informalmente e produziu apenas resultados em termos de acordos políticos para coordenar açóes, como a formulação do Plano Estratégico Metropolitano 2020 de Caracas, do qual participaram quase todas as administraçóes municipais, iniciado por seu prefeito, com a notória ausência do prefeito do município de Libertador.

Em 2017, a recém-eleita Assembleia Nacional Constituinte aboliu as duas entidades metropolitanas da Venezuela. Para justificar tal decisão, o decreto em questão argumentou, entre outros elementos, que o

nível metropolitano de Caracas (...), com seus órgáos e entidades vinculadas, como modelos de organizaçáo política administrativa, não garantiu seus propósitos (...) gerando um modelo de descentralização que deve estar sujeito a uma profunda reorganizaçáo para aproximar a gestão pública do poder popular, fortalecer a integração e articulação dos órgãos e entidades que os compóem e contribuir para garantir o bem-estar integral de suas populaçôes. ${ }^{69}$

\subsection{Reflexões sobre a Caracas metropolitana como estudo de caso}

Se levarmos em conta os resultados tímidos de sua gestão, defender a existência do Distrito Metropolitano ou da RM de Caracas seria uma tarefa árdua. No entanto, a abordagem deve ser outra: primeiro, a crescente complexidade das áreas metropolitanas e, mais ainda, das RMs, deve ser abordada com modelos de organização e administração públicas que não sejam a divisão tradicional do poder estatal (União-estado-município). A experiência comparada internacionalmente (Bogotá, Quito, Lima, para citar apenas três na América Latina), embora 
diferente, parece estar orientada para a criação de formas de organização e gestão metropolitanas diferentes das tradicionais.

Em segundo lugar, foi evidente a contradição entre o objeto de criação da RM de Caracas com as açôes da linha oficial do partido e do governo nacional, de não organizar políticas e estratégias e, consequentemente, gerar a impossibilidade de planejar e coordenar parte do governo metropolitano, de acordo com o fim dessa entidade territorial. Tudo isso aliado a uma política clara de centralização recente da vida política nacional, manifestada especificamente na posição de não abrir mão de espaços de governança metropolitana claramente, como redes de serviços.

O que foi uma conquista deste trabalho foi apresentar a inutilidade da área metropolitana de Caracas como uma unidade política territorial com base em sua ineficácia, quando um projeto institucional contraditório em si mesmo e vazio de conteúdo foi realizado, isto é, competências reais e capacidade de administração, bem como um projeto heterogêneo de muito pouca renda, aliado ao maior esforço para boicotar sua administração por meio de métodos passivos, como a não cooperaçáo institucional do partido do governo do governo nacional e o atraso na entrega de recursos.

\section{REFLEXÕES FINAIS}

$\mathrm{Na}$ Venezuela, em meados da década de 1980, começa o que chamamos de descentralização imperfeita, que, apesar de ainda mostrar sinais de dominação excessiva do poder central e de indefiniçóes no nível de concorrência de competências entre diferentes níveis de governo, mostrou a intenção de transferência de poderes entre os diferentes níveis de governo como política estatal. Foi um processo destinado a alcançar a democratização nacional por meio da descentralização político-administrativa (Delfino, 2005).

Então, um processo de centralização recente começou em 2006 com a criação dos conselhos comunitários e o estabelecimento do chamado Poder Popular. Esse processo começou privando os municípios de seus mecanismos para promover a participação dos cidadãos por meio das juntas de freguesia e associaçóes de bairro. Depois, ele usurpou as habilidades de planejamento e contribuiu para a transferência de poderes municipais para organizaçóes sem representantes eleitos democraticamente. Da mesma forma, os mecanismos de transferências intergovernamentais foram reformulados para beneficiar os conselhos comunais acima dos municípios.

A recente centralização também incluiu a transferência dos poderes exclusivos dos estados em termos de portos, aeroportos e estradas para o poder nacional. Os governos regionais também começaram a receber menos recursos com a modificação de diferentes leis que estabeleceram a transferência descentralizada 
de recursos estatais (Fides, FCI e LAEE), apesar do fato de que mais de 90\% da receita do estado depende de transferências do governo central. Finalmente, o Executivo nacional instalou órgãos descentralizados paralelos às províncias, sujeitos ao recebimento desses recursos. Essas medidas acabam de fato minando a autonomia dos governos regionais.

Finalmente, a recente centralização suprimiu os governos metropolitanos por meio de decretos. Isso ocorreu sem substituir a figura dos governos no nível supramunicipal, mas criando, no caso de Caracas, uma entidade territorial dependente do governo nacional que não cobre o território metropolitano da cidade.

O resultado foi a fragmentação do planejamento e da gestáo territorial na Venezuela, dado que os governos municipais, estaduais e metropolitanos foram impedidos de desenvolver planos e projetos de maneira coordenada e em escala, realizando investimentos viáveis em termos econômicos e técnicos. Em vez disso, um sistema nacional de controle do governo foi instalado em todo o território, principalmente por meio de organizaçóes comunitárias chamadas conselhos comunitários. Essa nova institucionalidade enfrentou vários desafios, como a baixa capacidade das organizaçóes comunitárias de desempenhar funçóes de gestão pública; a falta de mecanismos de garantia de transparência; e a ausência de representatividade democrática. $\mathrm{O}$ resultado acabaria afetando a qualidade dos gastos e investimentos públicos, cujo principal resultado é a perda no escopo e cobertura dos serviços públicos domésticos e a eficácia da participação do cidadão.

Do exposto, emerge uma reflexão final que consideramos relevante. $\mathrm{O}$ caso venezuelano pode servir de referência para outros casos de governança multinível no nível latino-americano: a arquitetura institucional deve buscar pontes que permitam a atenção das necessidades locais, mesmo na escala da vicinal, ao mesmo tempo que se promove um planejamento no nível metropolitano, incluindo o regional, bem como o desenvolvimento de processos de governança e controle multinível.

Esse processo é alcançado a partir de uma relação clara de competências entre os diferentes níveis de governo - daí a importância do nível metropolitano que permite articular uma escala intermediária entre os níveis municipal e nacional. Particularmente na Venezuela, o desaparecimento do nível metropolitano de governo tornou sua importância evidente. Lá, tornou-se cada vez mais perceptível que, do único ponto de vista da vizinhança, eles não podem atender, monitorar e controlar todas as necessidades, pois há numerosos problemas de infraestrutura - serviços como água ou transporte, cuja atenção requer integração intermunicipal. Ao mesmo tempo, tem sido virtualmente impossível abordar as particularidades de cada regiáo somente a partir do poder central, daí a 
importância da escala intermediária metropolitana para integrar as necessidades locais às estratégias regionais.

Contudo, o caso venezuelano também deixou claro que a mera criação de um nível de governo metropolitano não garante a clareza da governança nesse nível. O surgimento do evento metropolitano - e, mais ainda, da RM - implica a necessidade de uma redefiniçáo abrangente do Estado. Além do desenho de um governo metropolitano, é necessária a revisão de outros níveis do Estado, como os níveis nacional, estadual e municipal, para que essas instâncias reconheçam a importância do nível metropolitano. Isso inclui, a propósito, o aprofundamento do relacionamento institucional com a sociedade civil e outras instâncias no nível da comunidade.

No caso venezuelano, observou-se que o governo metropolitano foi visto como um empecilho pelos outros níveis de governo que são cumpridos por obrigação legal, mas sem entender o papel dessa instância para facilitar o planejamento territorial e a atenção às necessidades do cidadáo. Em resumo, a importância da governança metropolitana deve ser institucionalmente clara também nos outros níveis de governo. Para isso, além da clareza no design da arquitetura institucional, incluindo os graus de competências, definiçóes de funções e mecanismos de financiamento, é importante incluir outras ferramentas, como a geração de instituições que facilitem diferentes mecanismos de consenso, bem como o desenho de procedimentos que facilitam a resolução dos níveis de concorrência entre os diferentes níveis de governo.

Os dois aspectos anteriores trazem três preocupaçóes cuja resolução não pode ser totalmente esclarecida com o estudo do caso venezuelano. Este texto, portanto, nos permite recomendar pesquisas futuras que nos permitam aprofundar a compreensão do assunto: a flexibilidade da governança metropolitana, o estudo da governança multinível e a definição de modelos para uma estrutura institucional que facilite seu desenvolvimento.

Quanto à flexibilidade da governança metropolitana, o caso venezuelano deixou claro que, devido à crescente complexidade das áreas metropolitanas e, mais ainda, das RMs, deve-se avaliar a abordagem de modelos de organização e gestão pública que não sejam a divisão tradicional do poder estatal (República-estado-município). A questão levaria à geração de um modelo de gestão metropolitana, não necessariamente seguindo estruturas tradicionais, que permitam enfrentar os processos cada vez mais variantes da gestão urbana e ambiental de maneira mais dinâmica e flexível.

Em relação ao estudo da governança multinível, para a investigação do caso venezuelano, era essencial estudar também outros níveis de governo. Para o entendimento da recente centralização institucional na Venezuela, precisamos 
entender como isso também afetou os níveis municipal e estadual, com o intuito de entender as forças políticas e institucionais que geraram esse processo de recente centralização. Portanto, recomendamos a realização de pesquisas que estudem não apenas o nível metropolitano, mas uma governança multinível que permita entender a interação entre diferentes instâncias, com interesse especial no gerenciamento de conflitos de concorrência. Talvez a partir de uma institucionalidade multinível possam ser alcançadas estratégias de gestão inovadoras que não podem ser alcançadas apenas no nível metropolitano.

Quanto à definição de modelos para uma estrutura institucional que facilite a governança metropolitana, a Venezuela assumiu a criação de uma prefeitura metropolitana como instituição escolhida por votação universal, direta e secreta. Essa investigação mostrou que a experiência fracassada do caso venezuelano se deveu ao controle excessivo do poder central e às suas intençóes expressas de recentralização institucional como consequência de forte ímpeto autoritário. A eleição de um poder tâo importante quanto o do prefeito metropolitano foi vista menos como um contrapeso institucional e mais como um inimigo político que deveria ser eliminado.

Consequentemente, e devido ao fato de que a eficácia do modelo venezuelano não pôde ser verificada, esta pesquisa nos permite sugerir pesquisas futuras que possam avaliar a eficácia entre o mecanismo de eleição direta de um prefeito da RM em comparaçáo com outros modelos - como o de um governo metropolitano composto por representantes de outros níveis de governo, do municipal ao nacional, por colocar dois dos possíveis modelos institucionais que poderiam ser avaliados.

Finalmente, queremos finalizar enfatizando a importância de conceber a governança metropolitana como estratégia e ferramenta para fortalecer os processos democráticos. A experiência venezuelana nos mostrou que a democracia não é garantida automaticamente. Essa investigação evidenciou que a falida institucionalidade metropolitana de Caracas como unidade política territorial, com seu desenho institucional contraditório e conteúdo nulo - isto é, competências reais e capacidade de gestão, bem como um desenho heterogêneo de fontes financeiras que geram pouca renda - facilitou seu desmantelamento para a consolidação de uma abordagem autoritária que terminou em recente institucionalização. Nesse processo, também ocorreram métodos passivos de boicote à governança metropolitana, como a não cooperação institucional, o atraso na entrega de recursos e a ausência de mecanismos punitivos para quem violou a legalidade metropolitana. Esses dois processos, fragilidade institucional e obstrução dos processos de gestão, acabaram facilitando o desmantelamento definitivo das instituiçóes metropolitanas. 
$\mathrm{Na}$ Venezuela, a história do que chamamos de descentralização imperfeita apontou para uma abordagem progressiva das instituiçóes em relaçáo à participação dos cidadãos e se tratou de uma transformação política e cultural que levou muitos anos para se desenvolver e foi revertida em pouco tempo por conta da instalação de uma abordagem autoritária. A democracia não é garantida automaticamente - daí a importância de um estudo e de uma definição constantes de suas capacidades e limitaçóes institucionais.

\section{REFERÊNCIAS}

BREWER-CARÍAS, A. R. La distribución territorial de competencias en la Federación venezolana. Revista de Estudios de la Administración Local y Autonómica, n. 291, p. 163-200, 2003. Disponível em: <https://doi. org/10.24965/reala.vi291.9175>.

El inicio de la desmunicipalización en Venezuela: la originación del Poder Popular para eliminar la descentralización, la democracia representativa y la participación a nivel local. Asociación Internacional de Derecho Administrativo, p. 49-67, 2007.

. Sobre el régimen municipal en Venezuela. In: BARRERA, T. R. H. (Coord.). Derecho municipal multinacional. Ciudad de México: Porrúa, 2015. p. 653-694.

. La mutación del Estado federal en Venezuela. Revista General de Derecho Público Comparado, n. 23, 2018.

CARVAJAL, L. (Comp.). Educación, ciudadanía y democracia: memorias de la IV Asamblea Nacional de Educación, 9 y 10 noviembre 2007. Caracas: Editora UCAB, 2008.

DELFINO, M. de los A. Reflexiones sobre el distrito metropolitano de Caracas. Revista Venezolana de Economía y Ciencias Sociales, v. 8, n. 3, p. 131-149, 2002.

El proceso de descentralización político-territorial venezolano y su desarrollo constitucional y legislativo. Revista Urbana, v. 10, n. 36, p. 13-33, 2005. FRETES CIBILS, V.; TER-MINASSIAN, T. (Ed.). Descentralizando los ingresos fiscales en América Latina: por qué y cómo. Washington: BID, 2015. GARCÍA-GUADILLA, M. P. Crisis, descentralización y gobernabilidad urbana en el área metropolitana de Caracas. América Latina Hoy, n. 15, p. 43-48, 2009. Disponível em: <http://revistas.usal.es/index.php/1130-2887/article/view/2064>.

GILBERT, A. The Latin American city. 2. ed. London: Monthly Review, 1998. 
HELLINGER, D. Venezuela: tarnished democracy. Boulder: Westview, 1991. HERNÁNDEZ, J. I. Breves comentarios a la Reforma del Régimen de la Gestión Comunitaria de Servicios, Bienes y Otras Atributaciones. Caracas: Editora UCV, 2010.

. Sala Constitucional convalida la desnaturalización del municipio: notas sobre la sentencia no 355/2017 de 16 de mayo. Revista de Derecho Público de Venezuela, n. 149-150, p. 349-352, 2017.

LIEUWEN, E. Venezuela. 2. ed. London: Oxford University Press, 1965.

NEGRÓN, M. El crecimiento metropolitano vergonzante: la expansión en la segunda mitad del siglo XX. In: IMBESI, G.; VILA, E. (Comp.). Caracas: memorias para el futuro. Roma: Gangemi, 1995.

PAIVA, A. Caracas, en busca de un gobierno metropolitano. EURE, v. 27, n. 81, p. 43-59, 2001. Disponível em: <https://doi.org/10.4067/S0250$71612001008100003>$.

RÍOS, G.; ORTEGA, F.; SCROFINA, J. S. Sub-national revenue mobilization in Latin America and the Caribbean: the case of Venezuela. Washington: IDB, 2012. (Working Paper, n. 300).

SABATINO, J. La reversión de puertos en Venezuela. In: CONGRESO LATINOAMERICANO DE PUERTOS, 18., 2009, Miami, Florida. Anales... Miami: AAPA, 2009.

SALAS-BOURGOIN, M. A. Dinámica territorial del poder político en la Venezuela contemporánea (1961-2013). Revista Colombiana de Geografía, v. 25, n. 1, p. 95-109, 2016.

SÁNCHEZ MELEAN, J. Papel de la descentralización en la reinstitucionalización de la democracia. [s. 1.]: [s. n.], 2018.

URBINA MENDOZA, E. J. El derecho urbanístico en Venezuela (1946-2019): entre la tentación centralizadora y la atomización normativa de la ciudad venezolana sofocada. Caracas: Editorial Jurídica Venezolana, 2019.

URDANETA-TROCONIS, C. La gestión urbana del área metropolitana de Caracas. Caracas: Instituto Latinoamericano de Investigaciones Sociales, 2013. VENEZUELA. IX Censo Nacional de Población: 1962. Caracas: Ministerio de Fomento, 1962. 


\section{BIBLIOGRAFIA COMPLEMENTAR}

BARRIOS, S. La Caracas metropolitana. In: SEMINARIO INTERNACIONAL EL DESAFÍO DE LAS ÁREAS METROPOLITANAS EN UN MUNDO GLOBALIZADO, 2002, Barcelona, Espanha. Anales... Barcelona: ICCI, 2002. BREWER-CARÍAS, A. R. Instituciones políticas y constitucionales: el régimen histórico constitucional del Estado. Caracas: Editorial Jurídica Venezolana, 1996.

DELFINO, M. de los A. La gobernabilidad de Caracas Capital y el Distrito Metropolitano. Urbana, v. 6, n. 29, p. 35-45, 2001.

DISTRITO METROPOLITANO DE CARACAS. Ordenanza de funcionamiento del Consejo de Gobierno Metropolitano de Caracas. Gaceta Oficial, Caracas, 27 nov. 2001.

MAYA, M. L.; LANDER, L. Popular protest in Venezuela: novelties and continuities. Latin American Perspectives, v. 32, n. 2, p. 92-108, 2005. Disponível em: <https://doi.org/10.1177/0094582X04273870>.

RAY, T. F. The politics of the barrios of Venezuela. Berkeley: University of California Press, 1969.

TRIBUNAL SUPREMO DE JUSTICIA. Sentencia no 1.563 , de 13 de diciembre de 2000. Sala Constitucional, Caracas, 13 dic. 2000. Disponível em: <https:// vlexvenezuela.com/vid/alfredo-283506971>.

VENEZUELA. Resolución no 5 del Ministerio de Obras Pública. Gaceta Oficial, Caracas, n. 22.171, 26 nov. 1946.

. Decreto no 647 de la Junta Militar de Gobierno. Gaceta Oficial, Caracas, n. $23.576,19$ oct. 1950 .

. Decreto Reglamentario no 547 del Ministerio de Obras Públicas. Gaceta Oficial, Caracas, n. 25.392, 26 jun. 1957.

. Ley Orgánica de Régimen Municipal. Gaceta Oficial, Caracas, n. 2.297, 18 ago. 1978.

. Ley Orgánica de Ordenación Del Territorio. Gaceta Oficial, Caracas, n. 3.238, extraordinario, 18 ago. 1983.

. Reforma de la Ley Fondo Intergubernamental para la Descentralización. Gaceta Oficial, Caracas, n. 37.066, 30 oct. 2000.

- Reforma de la Ley de Asignaciones Económicas Especiales. Gaceta Oficial, Caracas, n. 37.086, 27 nov. 2000. 
Ley de Consejos Estadales de Coordinación y Planificación de Políticas Públicas. Gaceta Oficial, Caracas, n. 37.509, 20 ago. 2002.

. Ley Orgánica para la Planificación y Gestión de la Ordenación del Territorio. Gaceta Oficial, Caracas, n. 38.279, 23 sept. 2005.

Decreto no 2.830, de 1 de mayo de 2017. Gaceta Oficial, Caracas, n. 6.295, extraordinario, 1 mayo 2017. Disponível em: <https://www.sumate. org/documentos/Decreto_N_2.830_del_1_de_mayo_de_2017_Convocatoria_ Presidencial_Constituyente.010517.pdf>.

- Decreto constituyente mediante el cual se decide la supresión y liquidación del nivel metropolitano de Caracas y el Distrito del Alto Apure. Gaceta Oficial, Caracas, n. 41.308, 27 dic. 2017. Disponível em: <http://www. ghm.com.ve/wp-content/uploads/2018/01/41308.pdfs.

WHITE, H.; MENON, R.; WADDINGTON, H. Community-driven development: does it build social cohesion or infrastructure? A mixed-method evidence synthesis. New Delhi: 3ie, 2018. (Working Paper, n. 30). 
